Review

\title{
Review of Recent Drilling Projects in Unconventional Geothermal Resources at Campi Flegrei Caldera, Cornubian Batholith, and Williston Sedimentary Basin
}

\author{
Renato Somma ${ }^{1,2, *(\mathbb{D}}$, Daniela Blessent ${ }^{3}\left(\mathbb{D}\right.$, Jasmin Raymond ${ }^{4}\left(\mathbb{D}\right.$, Madeline Constance ${ }^{5}$, Lucy Cotton ${ }^{5}$, \\ Giuseppe De Natale $^{1}\left(\mathbb{D}\right.$, Alessandro Fedele ${ }^{1} \mathbb{D}$, Maria Jose Jurado ${ }^{6} \mathbb{D}$, Kirsten Marcia ${ }^{7}$, Mafalda Miranda ${ }^{4}$, \\ Claudia Troise ${ }^{1}$ and Thomas Wiersberg ${ }^{8}$
}

check for updates

Citation: Somma, R.; Blessent, D.; Raymond, J.; Constance, M.; Cotton, L.; Natale, G.D.; Fedele, A.; Jurado, M.J.; Marcia, K.; Miranda, M.; et al. Review of Recent Drilling Projects in Unconventional Geothermal Resources at Campi Flegrei Caldera, Cornubian Batholith, and Williston Sedimentary Basin. Energies 2021, 14, 3306. https://doi.org/10.3390/ en14113306

Academic Editor:

Paul Christodoulides

Received: 8 May 2021

Accepted: 2 June 2021

Published: 4 June 2021

Publisher's Note: MDPI stays neutral with regard to jurisdictional claims in published maps and institutional affiliations.

Copyright: (c) 2021 by the authors Licensee MDPI, Basel, Switzerland. This article is an open access article distributed under the terms and conditions of the Creative Commons Attribution (CC BY) license (https:// creativecommons.org/licenses/by/ $4.0 /)$.
1 Osservatorio Vesuviano, INGV, 80124 Naples, Italy; giuseppe.denatale@ingv.it (G.D.N.); alessandro.fedele@ingv.it (A.F.); claudia.troise@ingv.it (C.T.)

IRISS, CNR, 80134 Naples, Italy

3 Programa Ingeniería Ambiental, Universidad de Medellin, 050026 Medellin, Antioquia, Colombia; dblessent@udem.edu.co

4 Institut National de la Recherche Scientifique, 490 Couronne St., Quebec City, QC G1K 9A9, Canada; jasmin.raymond@inrs.ca (J.R.); mafalda_alexandra.miranda@ete.inrs.ca (M.M.)

5 GeoScience Limited Unit 1Falmouth Business Park, Bickland Water Road, Falmouth TR11 4SZ, UK; constance@geoscience.co.uk (M.C.); cotton@geoscience.co.uk (L.C.)

6 Geosciences Barcelona CSIC, 08028 Barcelona, Spain; mjjurado@csic.es

7 DEEP Earth Energy Production Corp. Box 6 Site 515 RR5, Saskatoon, SK S7K 3J8, Canada; kmarcia@deepcorp.ca

8 Helmholtz-Zentrum Potsdam-Deutsches GeoForschungsZentrum GFZ, 14473 Potsdam, Germany; wiers@gfz-potsdam.de

* Correspondence: renato.somma@ingv.it

\begin{abstract}
Unconventional geothermal resource development can contribute to increase power generation from renewable energy sources in countries without conventional hydrothermal reservoirs, which are usually associated with magmatic activity and extensional faulting, as well as to expand the generation in those regions where conventional resources are already used. Three recent drilling experiences focused on the characterization of unconventional resources are described and compared: the Campi Flegrei Deep Drilling Project (CFDDP) in Italy, the United Downs Deep Geothermal Power (UDDGP) project in the United Kingdom, and the DEEP Earth Energy Production in Canada. The main aspects of each project are described (geology, drilling, data collection, communication strategies) and compared to discuss challenges encountered at the tree sites considered, including a scientific drilling project (CFDDP) and two industrial ones (UDDGP and DEEP). The first project, at the first stage of pilot hole, although not reaching deep supercritical targets, showed extremely high, very rare thermal gradients even at shallow depths. Although each project has its own history, as well as social and economic context, the lessons learned at each drilling site can be used to further facilitate geothermal energy development.
\end{abstract}

Keywords: unconventional geothermal resources; geothermal drilling; communities; caldera; Enhanced Geothermal Systems

\section{Introduction}

Unlike other renewable energies, such as solar and wind, geothermal resources provide base-load power that can be generated continuously to meet the minimum level of power demand, independent of climate conditions. Resources are defined as conventional when found in hydrothermal systems related to magmatic activity and extensional faulting [1]. On the other hand, unconventional resources include Hot Sedimentary Aquifers (HSAs) with permeable layers at great depth $(2-5 \mathrm{~km})$, as well as Hot Dry Rocks (HDRs), which have been developed since the beginning of the 1970s and are now referred to as 
Enhanced Geothermal Systems (EGSs), where hot low permeable crystalline rocks are stimulated at drillable depths [2]. Heat transfer mechanisms in HSA and EGS are dominated by conduction associated with near normal heat flow for such petrothermal plays. Forced convection can be induced in deep aquifer layers to extract heat [3]. Other geothermal resources gaining interest are associated with supercritical fluids, which are characterized by temperatures between 390 and $600{ }^{\circ} \mathrm{C}$ and processed with superheated dry steam plants [4], while those of EGS and HSA are exploited with binary power plants, since the fluid temperature is usually $<150{ }^{\circ} \mathrm{C}$. Supercritical geothermal resources have been proven to exist at technically and economically viable depths, and one well extracting those resources can significantly increase the production output [4]. However, the extraction of energy from these resources is challenging because the permeability of the host material is at the brittle-ductile transition and the magmatic fluids produced are highly corrosive [5]. Calderas are possible candidates for the presence of supercritical geothermal reservoirs at shallow depth that have been explored in several countries [6-8]. Drilling through supercritical fluids in the scope of geothermal energy production was achieved by the IDDP project (Iceland Deep Drilling Project) [9].

While geological, geochemical, and geophysical exploration methods are used to estimate the size and temperature of the resources during the initial exploratory phase, deep drilling and well testing are required to prove resource viability [1]. Results obtained from drilling projects at key locations can be applied to other areas worldwide [10]. Moreover, since the installed costs and capacity factors of geothermal power plants are projectspecific, often the drilling of additional production wells is required to adjust the extraction mass flow rate and ensure the sustainability of the resource [11]. Deep drilling and reservoir stimulation can generate a negative social perception of geothermal energy within the communities living close to these kind of projects. Volken et al. [12] highlighted that geothermal energy acceptance in Switzerland decreased with increasing knowledge about geothermal development, probably as a result of learning about induced seismicity that occurred in the past [13]. Similarly, Malo et al. [14] demonstrated that the support to geothermal energy within the Quebec population in Canada can decrease by $10 \%$ when exposed to the potential impacts of reservoir stimulation. In contrast, Carr-Cornish and Romanach [15] showed a positive change in perception when people acquired more information and knowledge about geothermal energy. Pellizzone et al. [16] revealed that the perception of renewable energies, including geothermal energy, is generally positive and optimistic, but, like Carr-Cornish and Romanach [15], indicated that when a geothermal project is developed in the area, the confidence of the affected population decreases, giving rise to the phenomenon known as "Not in my backyard" (NIMBY). However, where deep drilling and subsurface exploration are a common practice, such as developed oil fields or mining regions, drilling for deep geothermal resources can be socially accepted given the local comfort from historical experience and transferable expertise to maintain jobs.

In this paper, three drilling geothermal exploration projects conducted in Italy, the United Kingdom, and Canada are described to provide an overview of recent geothermal development. The common element of these projects is that they target unconventional geothermal resources: the Campi Flegrei Deep Drilling Project (CFDDP) in the volcanic caldera located Southern Italy west to Naples metropolitan area, the United Downs Deep Geothermal Power (UDDGP) project in hot granite rocks located in the Cornwall county in South West England, and the DEEP Earth Energy Production Corp. project in Canada, targeting HSA in the Western Canadian Sedimentary Basin.

Although these three countries went forward with geothermal drilling projects, their geothermal power generation backgrounds are different. In Europe, geothermal power plants were installed by the beginning of 1900 in Italy, but there are not yet geothermal power plants in the United Kingdom. Likewise, no geothermal power plants are operating in Canada, but several recent exploration projects have been conducted [17]. While the CFDDP drilling activities were conducted in 2012, those of the UDDGP and DEEP projects are more recent, since they were concluded in 2019 and 2020, respectively. One of the 
targets of the CFDDP were supercritical fluids, while the shallow pilot hole drilled so far has not reached those fluids. However, this area shows very high geothermal gradients at shallow depths, thus allowing unusually shallow, cheap, and powerful geothermal exploitation. On the other hand, the UDDGP and DEEP projects focus on geothermal resources outside volcanic areas reaching the same temperature of the CFDDP pilot hole far deeper. The social context and communication strategies with the local communities are also different: Campi Flegrei is a highly populated volcano, while the Cornwall county and the Saskatchewan province have a lower population density with local comfort and history from drilling oil and mining exploration wells. Therefore, the objective of this paper is to review the recent geothermal exploration work at those three key projects and synthetize new knowledge gained that can be used in other countries looking to expand geothermal energy production.

\section{Geothermal Energy in Italy}

Italy is the first country in the world where geothermal energy was used for power generation at the beginning of the twentieth century. Geothermal resources are mainly used for electricity generation in Tuscany. The installed electrical capacity at the end of 2020 was of 944 MW, leaving Italy outside the "1 GW geothermal country club" [18].

In the Neapolitan area (Southern Italy), 116 deep wells were drilled for geothermal exploration between 1930 and 1980, i.e., 26 of them in Campi Flegrei [19] and 90 of them on the Ischia island. At Campi Flegrei, it is expected that temperature exceeds the critical point of water at depths as shallow as $2.5-3.0 \mathrm{~km}$, whereas the thermal output of Neapolitan volcanic areas exceeds $16 \mathrm{GWt}$ [19]. The CFDDP project would contribute to further improve the knowledge about the geothermal resources in this area, from very high shallow geothermal gradients down to the supercritical areas [20].

\subsection{The Campi Flegrei Project}

The choice of Campi Flegrei as a target for the deep study of large calderas is justified by the evidence-from previous drillings and from recent deformation and seismic observations - that the main structures of volcanological interest are considerably shallower than in other well-studied similar calderas [21]. This also implies the presence of extremely high geothermal gradients, with supercritical temperatures found at depths as shallow as 2.5-3.0 km [19]. The Campi Flegrei caldera (CFc) (Figure 1) is a typical example of the most explosive volcanoes on the Earth, namely large collapse calderas. It was formed from a main collapse event related to an ignimbritic eruption occurring $15 \mathrm{ka}$ ago [21,22], named Neapolitan Yellow Tuff (NYT).

In the framework of the International Continental Scientific Drilling Program (ICDP), the pilot hole of Campi Flegrei Deep Drilling Project (CFDDP) [20] was drilled down to a depth of $500 \mathrm{~m}$ for understanding the stratigraphy and eruptive history of the easternmost caldera border, which lacked previous drilling and remained less studied. One additional objective was to evaluate the possibility of drilling a $3500 \mathrm{~m}$, deviated deep hole, with deviation starting at about $500 \mathrm{~m}$ of depth.

The CFDDP had passed through a long evaluation process by ICDP, before the approval of the scientific and technical project, to obtain the authorization and economic support to proceed. There was an important debate during this period in the local and international scientific communities because drilling in the caldera had not been conducted since the middle of the eighties. The area was further affected by uplift and frequent low-magnitude seismic activity (generally lower than magnitude 2, but with peaks of magnitude 4.2 in the 1980s). Such ground dynamics, with $0.76 \mathrm{~m}$ of uplift in the last fifteen years, increasing seismicity, together with the memory of the previous large unrest of the 1970s and 1980s, raised concern in the population about the usefulness and risks of CFDDP. Such a concern was first claimed by a local geologist and then shared and amplified by newspapers and media, worrying the community and the local authorities. In summary, while almost all the national and international scientific community agreed on 
the usefulness of the project and on the absence of risks for the population, few geologists from Naples University argued in an unscientific way about risks due to the drilling of the CFDDP, not only the deep well, but also, specifically, the pilot hole targeting $500 \mathrm{~m}$ of depth only. Confusion was mainly associated with a possible volcanic eruption triggered by the pilot hole in the caldera, since a misunderstanding occurred when translating "gas blowout" that may occur during well drilling and this was confused with volcanic eruption. This potential risk was amplified by the media and rapidly spread worldwide. In 2010, the INGV, which is appointed to mitigated volcanic risk, was accused to endanger the community with its scientific activities. Although this situation was recognized as lacking any scientific background within the international scientific community, at the local level, the criticism made by geologists was influencing the opinion of local authorities and population. This situation, leading to unsuitable communication between scientists, authorities, and communities, resulted in a delay of about two years in the pilot hole drilling.

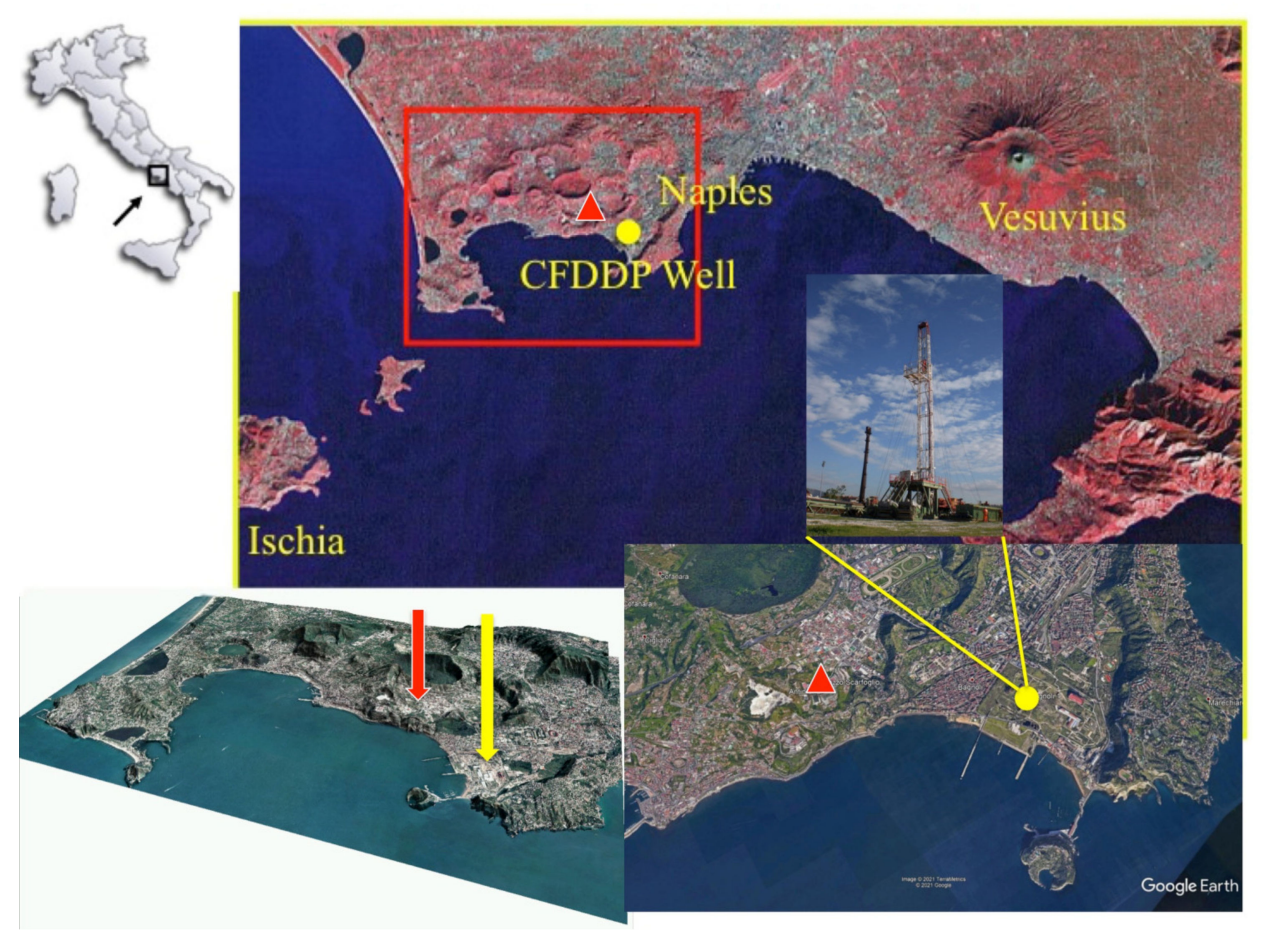

Figure 1. An overview of the Neapolitan volcanoes from a satellite image, with Campi Flegrei caldera evidenced in different points of view. The site of the Bagnoli 1 borehole CFDDP (yellow circle) and the Agnano geothermal well (red triangle) are also shown on the maps.

Drilling was conducted two years after, in 2012, in the Bagnoli plain: from 22 to 29 July until a depth of $222 \mathrm{~m}$, and then from November 22 to December 2 to the depth of $506 \mathrm{~m}$. This drilling site is an old dismantled industrial area located in Western Naples (Figure 1 of about $2 \mathrm{~km}^{2}$ chosen for several scientific and logistic reasons [23]: the eastern part of the caldera had not been drilled before at a considerable depth, as this area is the most populated and faces the most geohazards. For these reasons, the aim of CFDDP was to study such an unexplored side of the caldera, where the local deposits are mostly unknown, although they pose the highest risk to the large city of Naples.

While the study of the rock properties helped to refine the thermo-hydro-mechanical modeling of the unrest processes [24], the stratigraphic studies and relative rock dating by radioisotope methods gave fundamental insight into the evolution of the area, as well as the caldera formation and extension [20]. At that time, the caldera was thought to have been formed by the Campanian Ignimbrite eruption (40 ka BP), and then collapsed again, in the innermost part, during the NYT eruption (15 ka BP). The Campanian Ignimbrite caldera was thought to include the city of Naples, so largely overcoming the Posillipo 
Hill [24], which, on the other hand, was thought to represent the easternmost limit of the NYT caldera.

\subsubsection{Pilot-Hole Mud-Gas Analysis}

Real-time mud-gas analysis was performed during drilling to discuss the correlation between lithology and gas distribution. A detailed methodological description was given by Erzinger et al., 2006 [25]. In fact, on-line mud-gas monitoring is a reliable and costeffective way of continuously investigating the distribution of gases versus depth, because it does not require rig-time. Because the mud gas may help to characterize origin of fluids and fluid interaction, the real-time mud-gas analysis can help to better understand the hydrothermal behavior with respect to CFc. Geochemical analysis in the CFDDP was conducted in a field laboratory to obtain information on gases and their composition in drill mud.

To dissolve the gas in the drilling mud, a custom-built water-gas separator was used and made of a steel cylinder ( $30 \mathrm{~cm}$ diameter, variable height) with an explosion-proof electrical motor on top that drives a stirring impeller mounted inside the cylinder [26]. The degasser was installed immediately behind the outlet of the mudflow line to reduce air contamination. The gas was then extracted and pumped with a membrane pump through a PTFE tube ( $4 \mathrm{~mm}$ inner diameter) into an on-site mud-logging cabin (about $20 \mathrm{~m}$ away from the hole) and led into an OmniStar ${ }^{\circledR}$ (Asslar, Germany)Quadrupole Mass Spectrometer (QMS; Pfeiffer Vacuum ${ }^{\circledR}$, Alssar, Germany; Figure 2).

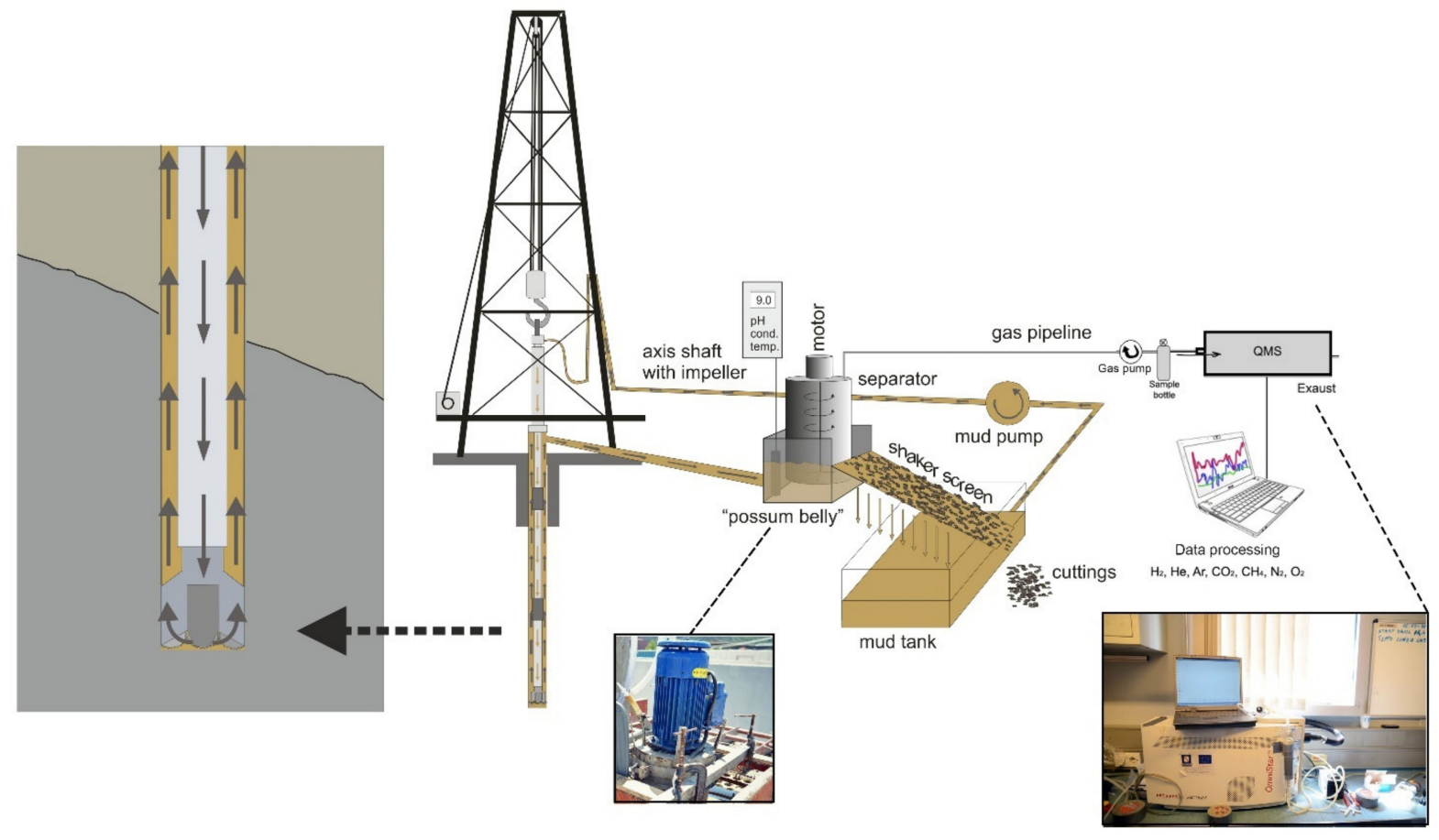

Figure 2. Sketch of the experimental setup. Gases entering the borehole are transported to the surface, together with the drill mud. A degasser extracts the gases from the drill mud. The gases are pumped to a lab trailer and analyzed in real time with a Quadrupole Mass Spectrometer (QMS).

Before introducing the gas into the QMS, the gas was passed through a water trap to remove moisture. The pressure of the gas to be measured is reduced from atmospheric down to $4 \times 10^{-6}$ mbar by differential pumping through a $1.2 \mathrm{~m}$ long capillary with $0.15 \mathrm{~mm}$ diameter and an orifice (0.02 $\mathrm{mm}$ diameter). When gas flow into the mass spectrometer is interrupted, a background pressure of $\sim 7 \times 10^{-8} \mathrm{mbar}$ is achieved (for details, see Reference [27]). 
The QMS was recalibrated, when necessary, with air, pure $\mathrm{CO}_{2}$, and certified gas mixtures, the compositions of which are selected according to the expected composition of mud gas. A time correction was applied to the gas composition data according to the measured and calculated mud-flow lag time, to compare the gas data to the drilling depth. A complete analysis of $\mathrm{Ar}, \mathrm{CO}_{2}, \mathrm{CH}_{4}, \mathrm{He}, \mathrm{H}_{2}, \mathrm{O}_{2}$ and $\mathrm{N}_{2}$ in the drilling mud gas was determined after an integration time of $20 \mathrm{~s}$. However, measurements were recorded minutely to reduce the amount of data with detection limits of one $\mathrm{ppm}_{\mathrm{V}}$ and absolute analytical uncertainties of $1 \mathrm{ppm}_{\mathrm{v}}$ for concentrations $<10 \mathrm{ppm}_{\mathrm{v}}, \sim 2-4 \mathrm{ppm}_{\mathrm{v}}$ for concentrations $<100 \mathrm{ppm}_{\mathrm{V}}, \sim 5-20 \mathrm{ppm}_{\mathrm{V}}$ for concentrations $<\mathrm{ppm}_{\mathrm{v}}$ and $0.02-0.1 \%$ for concentrations $>1$ vol. \%. From all the analyzed gases, only $\mathrm{CO}_{2}, \mathrm{CH}_{4}$, and $\mathrm{He}$ are diagnostic of fluid inflow [25] because these gases are variably enriched in natural deep fluids but are only present in low concentration in the atmospheric air. Moreover, He, like all noble gases, is not affected by alteration of drilling mud or by chemical reactions. Although determination of $\mathrm{Ar}, \mathrm{H}_{2}, \mathrm{O}_{2}$, and $\mathrm{N}_{2}$ were also performed, relative concentrations of these gases can originate from sources other than fluid inflows, such as air contamination or chemical reactions with the drill mud, casing, and drill tools.

\subsubsection{Correlation with Logging Measurements}

A set of geophysical logging measurements were acquired by using hydrocarbon exploration standard borehole logging tools. Spectral natural gamma and acoustic logs, as well as resistivity-oriented images, were acquired to characterize rock composition, physical properties, structures, and geometries intersected by the CFDP-1 borehole. The logging data were acquired in two different surveys, using Schlumberger equipment, following the drilling of an upper and a lower section. The first logging operation performed in open-hole mode in July 2012 (31-170 m) (12.25 in borehole) in the upper section and included FMI (Full Bore Imaging) resistivity imaging and total natural gamma profile, as well as spectral gamma data with the HNGS Schlumberger tools and Sonic Scanner Schlumberger tool. In November 2012, additional geophysical logs were acquired during a second log-measurement operation (219-430 m section) in the open hole ( 8.5 in borehole).

The second logging run included imaging with the FMI tool HNGS spectral gamma measurements and acoustic profiling with the DSI (Dipole Shear Image) Schlumberger tool. This set of measurements is a unique continuous record that has been used to analyze and interpret the geological and petrophysical properties of the rocks drilled at the CFDDP drill hole [28]. The oriented resistivity images allowed the analysis of the geometries and orientation of the volcanic rock bodies, textures, structures, compositional changes, and the main discontinuities. To identify possible correlations between log measurements and gas anomalies, we used spectral natural gamma spectroscopic data as our first approach. This measurement yields gamma spectroscopy profiles in \% for $\mathrm{K}$, and ppm for $\mathrm{U}$ and Th [29-31]. These data are the expression of both the rock composition and the presence of radiogenic elements. It was observed that gas concentrations vary with different lithologies; therefore, we analyzed the correspondence and possible relationship with spectral data changes and fluctuations.

The data displayed on Figure 3 show overall total gamma value that is low with some increases related to compositional changes (e.g., at $\sim 60 \mathrm{~m}$ ) and in this case, the presence of organic-matter-rich levels [20,32]. 


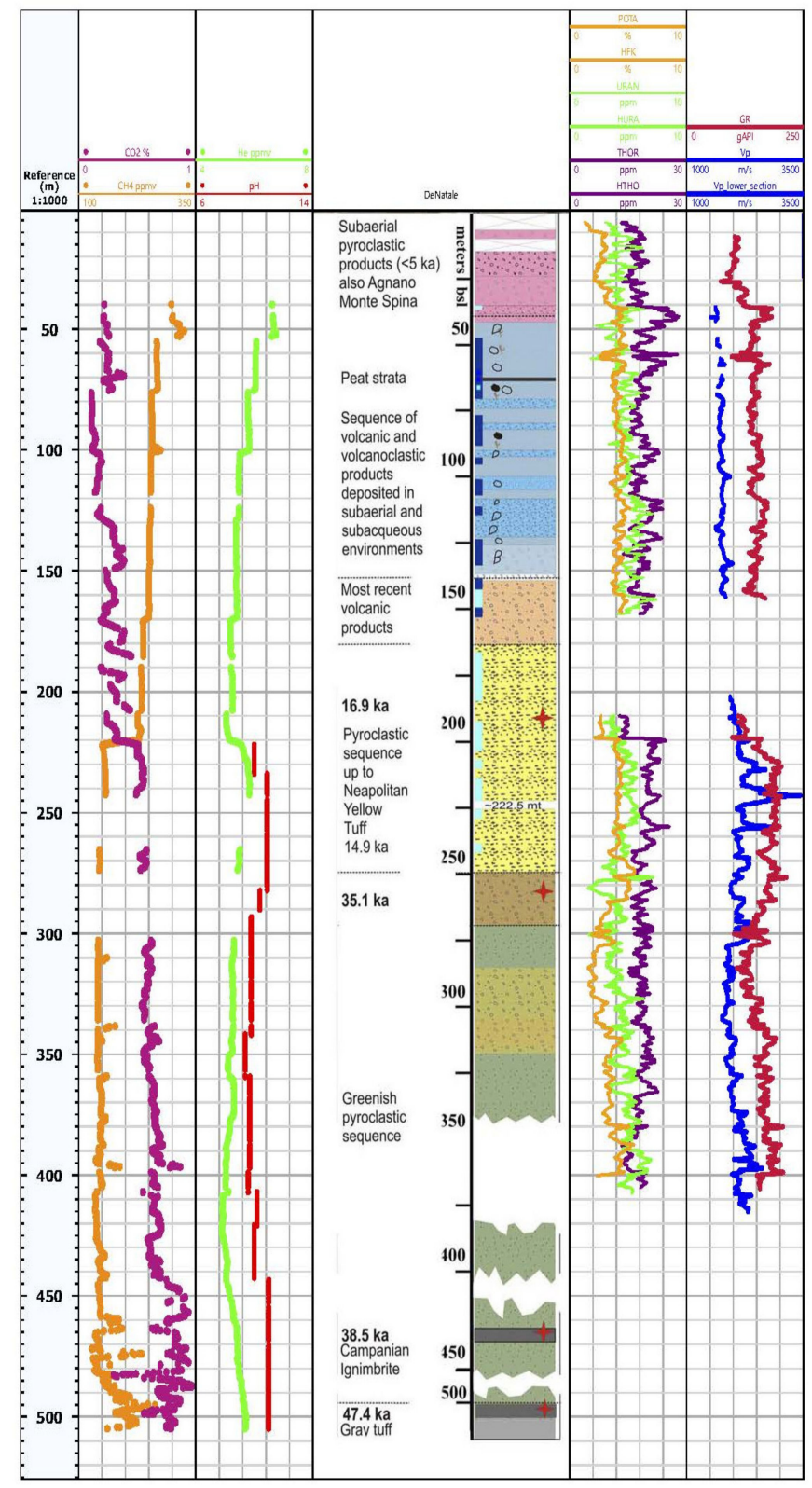

Figure 3. On the left-hand side, depth-profile of $\mathrm{CO}_{2}, \mathrm{CH}_{4}$ and $\mathrm{He}$, measured in the drill mud during drilling and associated lithology intercepted by the borehole. On the right-hand side (where the stratigraphic column is not scaled in the lower section and the logging data did not reach total depth of the well); wireline logging measurements ( 2 intervals) of spectral gamma radiation $\mathrm{K}$, Th, and $\mathrm{K}$ content (first track); and total gamma radiation displayed with $\mathrm{v}_{\mathrm{p}}$ and $\mathrm{v}_{\mathrm{s}}$ acoustic velocities, on the second track.

At the boundary between pumice to scoria deposits at a depth of $160 \mathrm{~m}$, a shift in gamma values from 160 to $180 \mathrm{gAPI}$ is observed. Another change observed in total gamma values, as well as in the $\mathrm{K}, \mathrm{U}$, and Th concentrations, is observed at $280 \mathrm{~m}$. In this case, the change can be related to the lithological boundary with the first appearance of the greenish tuff deposits. K (1 to $5.5 \mathrm{wt} \%)$, Th (10 to $28 \mathrm{ppm})$, and U (1 and $6 \mathrm{ppm}$ ) concentrations (Figure 3 ) agree with the range of values of surface sample analyses from Campi Flegrei [33-35]. The sonic velocity data's quality is affected by the borehole conditions (irregular diameter) caused by the poorly consolidated rocks that can be inferred from the caliper log. Shear wave velocity measurements were especially affected by these borehole conditions. The compressional p-wave values are of good quality and can be used to analyse the rock properties. At a $260 \mathrm{~m}$ depth, and coincident with the base of the Neapolitan 
Yellow Tuff sequence, increased Vp values are observed $(3000 \mathrm{~m} / \mathrm{s})$. A good correlation is observed between the gamma radioactivity and $\mathrm{pH}$ along the Neapolitan Tuff formation at a depth ranging from 220 to $280 \mathrm{~m}$ (Figure 3).

\subsection{From the Pilot Hole to the Deep Drilling}

One of the aims of the pilot hole was to better understand the conditions of temperature, stress, and rock properties in the shallower substructure to plan the deep drilling, since the deviation towards the center caldera requires knowing the temperature at depth. In fact, electronic devices needed to perform the correct deviation cannot sustain temperature greater than about $150{ }^{\circ} \mathrm{C}$. The temperature found at less than $500 \mathrm{~m}$ of depth in the former ENEL-AGIP drillings on the other side of the caldera exceeded $200^{\circ} \mathrm{C}$. Moreover, in the neighboring area of Agnano, about $2 \mathrm{~km} \mathrm{N-NW}$ of Bagnoli, temperatures exceeding $100^{\circ} \mathrm{C}$ can be found at depths as shallow as a few tens of meters. The Bagnoli borehole showed a temperature of about $110{ }^{\circ} \mathrm{C}$ at $500 \mathrm{~m}$ of depth, thus being compatible with the deep hole deviation at $500 \mathrm{~m}$. Moreover, the high temperature gradient in parts of the caldera combined with seismic tomography $[36,37]$ suggest highly pressured gas reservoirs may be found at a relatively shallow depth. However, the $500 \mathrm{~m}$ Bagnoli well did encounter such conditions. The CFDDP pilot hole, therefore, gave important results about the thermal and hydraulic rock properties and shallow stratigraphy indicating favorable conditions for a deep deviated drilling to find supercritical fluids deep down at the same site (Figure 4).

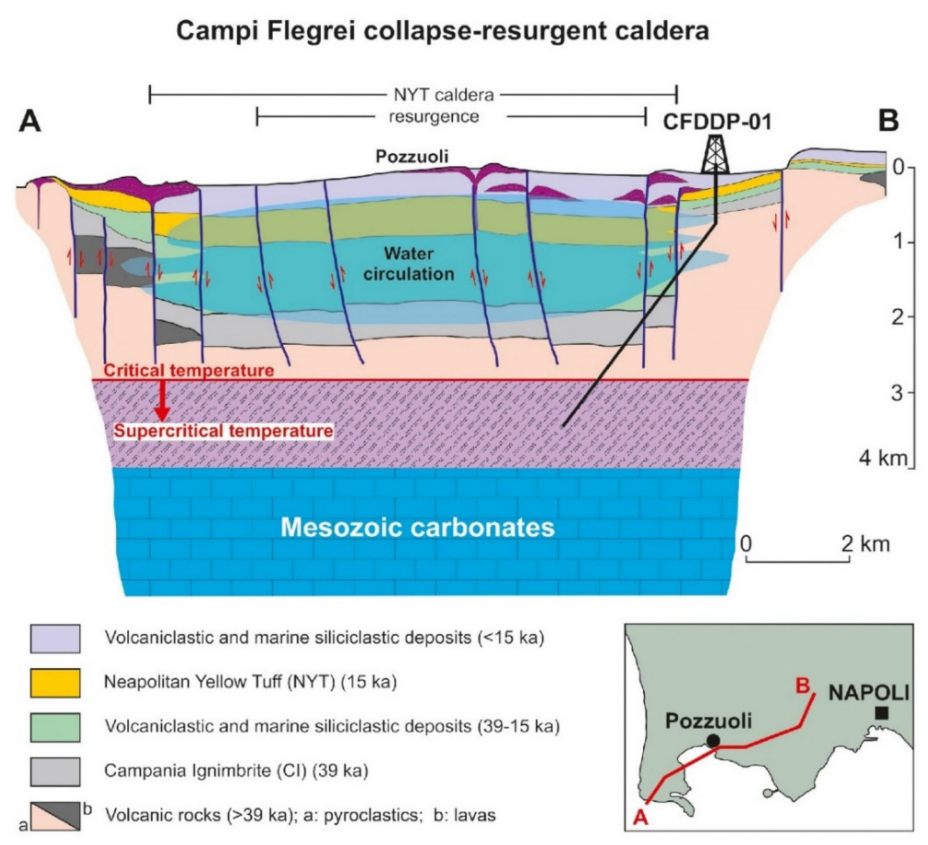

Figure 4. Schematic representation of the Campi Flegrei caldera structure indicating the proposed onshore deep inclined borehole CFDDP-01. Modified from Reference [38].

Following the results of the pilot hole, a further well, specifically aimed to find the areas of highest temperature gradients at very shallow depths, and hence the most suitable for inexpensive and powerful geothermal exploitation, was drilled in the AgnanoPisciarelli area (red triangle in Figure 1). The measured temperature-depth profiles of the two wells are shown in Figure 5 [39]. The Agnano borehole samples the area of highest shallow geothermal gradient, with temperature exceeding $110^{\circ} \mathrm{C}$ found at only $88 \mathrm{~m}$ of depth, showing the very high potential of this area, already quantified by Reference [19], even at very modest and inexpensive depths. 

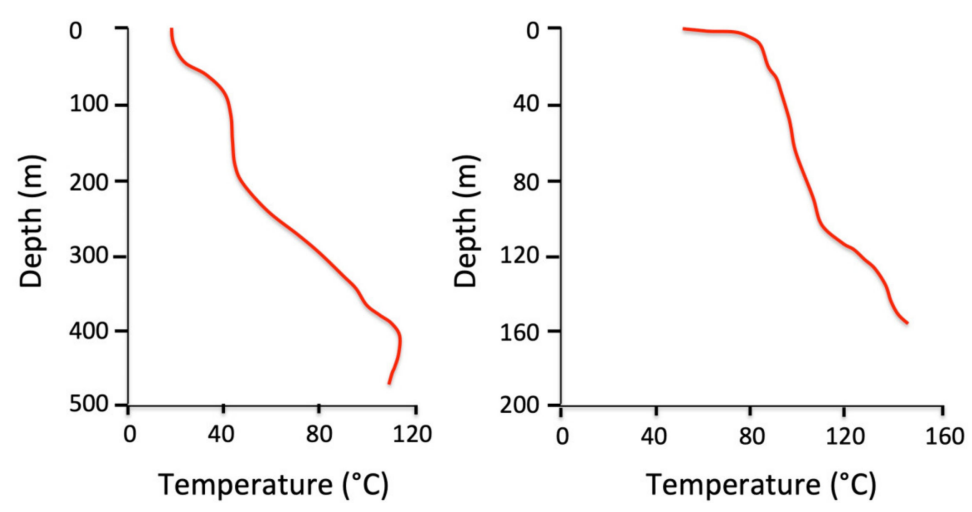

Figure 5. Temperature profiles of the Bagnoli 1 well ((left), Reference [39]) and of the Agnano well ((right), measured with thermocouple probe).

\section{Geothermal Energy in the UK}

The UK is not typically considered to be a country of significant geothermal energy potential, since it is located far from tectonic plate boundaries and is not volcanically active. Investigation into the UK's geothermal energy potential was instigated in the wake of the 1973 oil crisis. In the Cornwall region, characterized by a long mining history, elevated temperatures were measured in deep tin and copper mines [40]. These were later proven by heat-flow studies and geothermal assessments conducted by the BGS (British Geological Survey) [41,42]. In 1974, systematic heat-flow studies in the region revealed anomalously high values across the Cornubian Batholith (c. $120 \mathrm{mWm}^{-2}$ ), more than double the UK average [43-45], due to the high concentrations of "heat producing" radioelements uranium, potassium, and thorium within the granites. Needless to say, it has long been known that the "rocks are hot down there", and in the 1970s, the "Hot Dry Rock" project was conducted off the back of this knowledge to explore the potential of Cornwall's untapped geothermal resource. The HDR Geothermal Project (1974-1991) was pioneered by Camborne School of Mines and was located $7 \mathrm{~km} \mathrm{SSW}$ of the recent UDDGP project [46]. The results from the HDR project were fundamental to the development of UDDGP, influencing both site selection and well design [47].

Cornwall is geologically known as the Cornubian Massif, part of the Variscan Massif, that is surrounded by Permian and younger offshore sedimentary basins [48]. Granites associated with the Cornubian batholith outcrop as six main plutons in the upland areas (Figure 6a). The thickness of the granite mass is not known, but from geophysical studies and the high heat-flow values, it is thought to be several kilometers. The granites of the Cornubian batholith, and Devonian host-rock formations, are crosscut by extensive NW-SE to NNW-SSE striking strike slip fault zones (Figure 6b). NW-SE to NNW-SSE striking fault zones displace earlier formed ENE-WSW striking extensional, magmatic hydrothermal lodes, and experienced selective post-Triassic reactivation and fluid migration [49]. The Porthtowan Fault (PTF) zone targeted at UDDGP is a NNW-SSE striking complex strikeslip fault zone belonging to this family of sub parallel fault structures in SW England. 

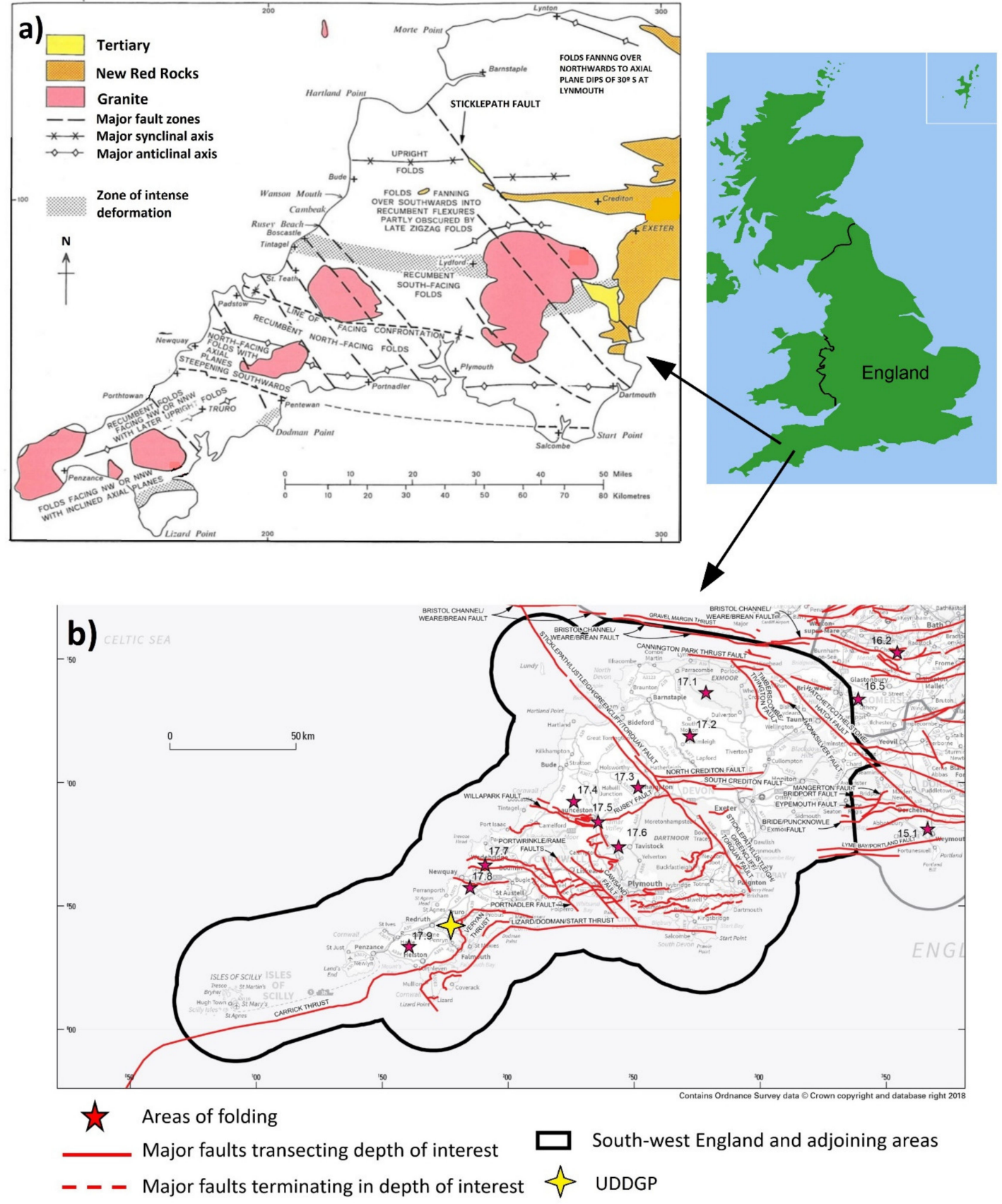

Figure 6. (a) Major faulting across the SW of England and granite location [50]. (b) Major faults and areas of folding in the South West England region, and location of the UDDGP project, Contains Ordnance Data @ Crown Copyright and database rights 2018. Ordnance Survey License no. 100021290. Contains British Geological Survey digital data @ UKRI 2018 [51].

\subsection{The United Downs Deep Geothermal Power Project}

The UDDGP project is the first of its kind in the UK and is located near Redruth in Cornwall. The project is predominantly funded by the European Regional Development Fund and Cornwall Council as well as some private match funding. The deeper production well (UD-1) is currently the deepest onshore well in the UK, at a vertical depth of $5057 \mathrm{~m}$ TVD, and was completed in April 2019. The injection well (UD-2) was completed 3 months later at the end of June 2019 to a depth of $2205 \mathrm{~m}$ TVD. These wells were drilled by using the Innovarig, a new-generation semi-automatic hydraulic rig (Figure 7a). The large well separation of over $2000 \mathrm{~m}$ is unique and was developed for two reasons: firstly, to help prevent the geothermal system from "short circuiting" and negatively impacting 
the temperature performance (as was experienced in the 1980s HDR project) and secondly to try develop a deep geothermal system that is more economic and therefore commercially viable. Both wells are deviated towards the WSW at depth to intersect the PTF (Figure $7 \mathrm{~b}$ ). This steeply dipping NNW striking structure was identified as having enhanced permeability during the feasibility stage from the mining records, which showed both occurrences of hot springs along its strike length and hydrocarbon seeps close to the fault zone. When combining its surface expression with observations from the mining records and aeromagnetic data, the PTF is thought to have a strike length of $>15 \mathrm{~km}$ and a nominal width of c. $400 \mathrm{~m}$ containing a complex zone of braided fault strands with relays, overstep, and jogs, with opposing dips and senses of displacement on individual strands [40].

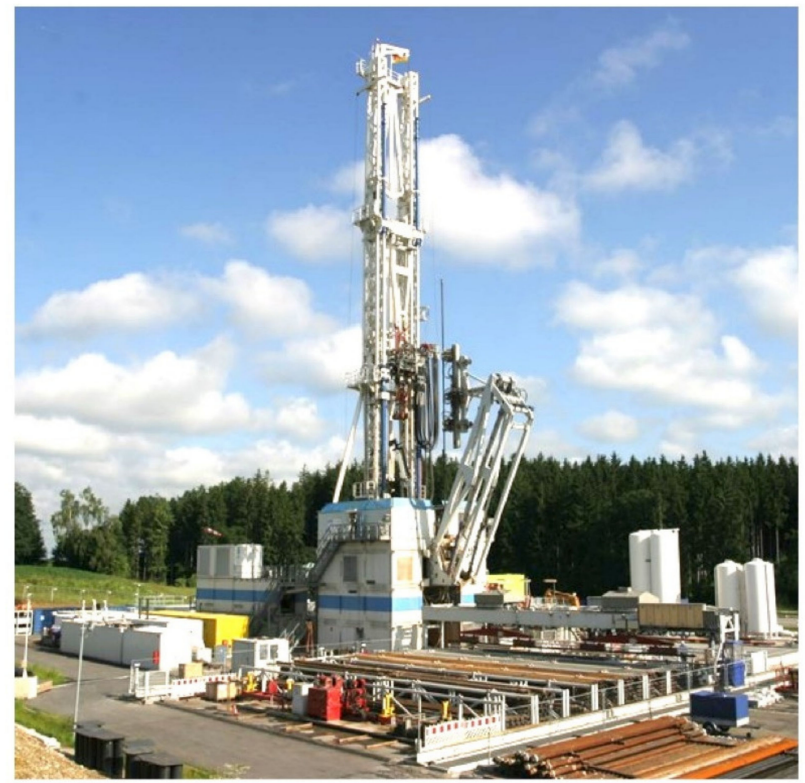

a)

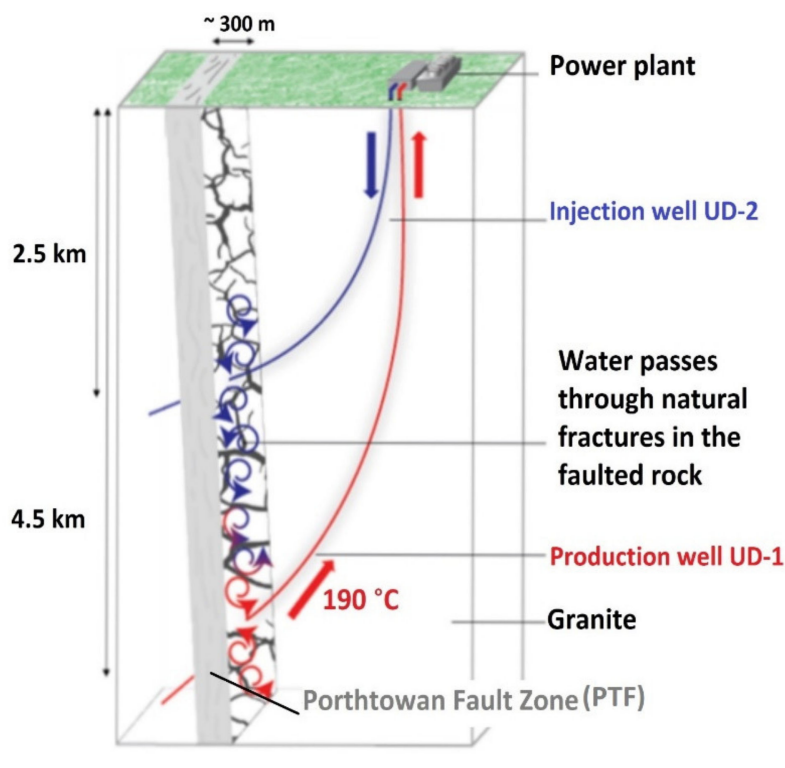

b)

Figure 7. (a) The Innovarig hydraulic rig [52]; (b) schematic section with the production well (UD-1), injection well (UD-2), and Porthtowan Fault (PTF), modified from Reference [53].

\subsubsection{Analysis of Drill Cuttings}

Samples of drill cuttings were collected every $10 \mathrm{~m}$ and every $5 \mathrm{~m}$ once in or close to the target structure. Further cuttings samples were taken at bit changes and at sudden changes in drilling parameters, mud samples were taken every $12 \mathrm{~h}$. Upcoming lithology and fractures were hard to predict since mining records in the area ceased at $400 \mathrm{~m}$ and no geophysical data were available. For this reason, it was essential to collect as much down-hole data while drilling to predict and correctly identify the Porthtowan Fault zone. Three main lithologies were encountered during the drilling of UD-1 and UD-2 at United Downs: metasediments (killas), microgranite, and granite.

Metasediments were found in the upper $210 \mathrm{~m}$ of UD- 1 and were dominated by highly deformed, low-grade regionally metamorphosed and deformed mudstones of the Upper Devonian Mylor Slate Formation [54]. This lithology contains hard metamorphic quartz veins of late Variscan age, formed before the intrusion of the granite. QEMSCAN analysis of samples from the upper $210 \mathrm{~m}$ of UD-1 showed traces of mineral assemblages akin to those encountered during the formally mined steeply dipping lode systems within the slates of the United Downs mining district (Figure 8). The results included a range of oxide-sulfide mineralization, showcasing nearly every mineral that have been exploited in this area, including occurrences of tin, copper, zinc, and wolframite. 


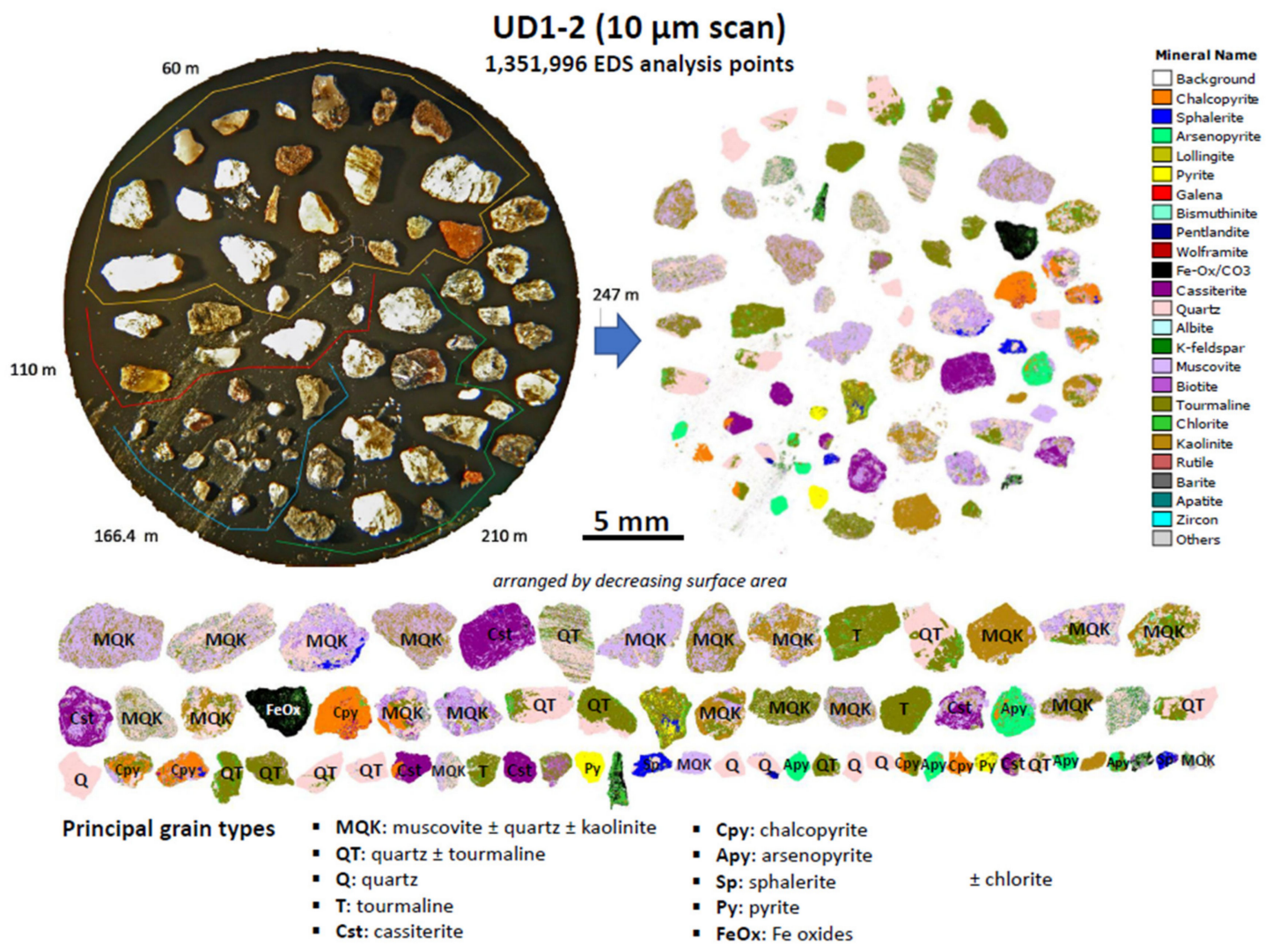

Figure 8. QEMSCAN analysis from the top $210 \mathrm{~m}$ of UD-1, accredited to CSM (Camborne School of Mines).

Both UD-1 and UD-2 penetrated heavily griesened and kaolinized fine grained "microgranite" from $210 \mathrm{~m}$ MD to c. $740 \mathrm{~m}$ MD. Although unexpected at the time, this lithology has since been accredited to NNW-dipping microgranite-rhyolite dyke, locally termed "Elvan" which was mapped at surface by the BGS in 1989.

Almost all unaltered samples of granite were muscovite dominant and corresponded with definitions of two mica granite and muscovite granite as recently redefined by the reclassification of Cornubian granites [55]. Further, nearly all coarse cuttings below $740 \mathrm{~m}$ plotted within the monzogranite field on the QAP classification which was consistent with the granites encountered during the HDR project at Rosemanowes some 5 miles away. Notable variations of texture and mineralogy with regard to the assemblage of accessory minerals led for further classification of the granite. The radiogenic classification of granites split the granite into four types, depending on their U/Th ratios from the spectral gamma data during wireline logging and helped to constrain and understand the heat-flow values.

\subsubsection{Education and Community Outreach}

The emphasis on community engagement from the outset of the project was critical to gain an SLO (Social License to Operate). The geothermal development was a high-profile project that attracted a lot of attention: communication was a high priority and was a unique and successful part of the project, which, if possible, should be emulated elsewhere. Since the UDDGP project is the first of its kind in the UK, the geothermal concept being tested at the site, as well as the associated deep-drilling technology, is new and unfamiliar, and unfamiliarity often leads to concern. Therefore, gaining a SLO was imperative to enable further development and growth of the industry. Although deep drilling for geothermal energy is relatively new to the region, subsurface exploration for natural resources is not unfamiliar to Cornwall given its long mining history. Effective science communication is key to the understanding and acceptance of new projects, and therefore high priority was given to education and communication of the project, with the overall objective of making 
the maximum amount of information easily accessible to all members of public, and to encourage direct communications with project staff.

The UDDGP education program was designed around two key focuses: a gap in taught subjects and growing a new industry, with the aim of making education about geothermal and its potential in Cornwall, and the UDDGP concept available to all ages across all subject areas. It was designed for students between the ages of 7-21 years and split into specific age groups according to the English education system: KS2 (7-11 years), KS3 (11-14 years), KS4 (14 years+), and higher/further education, for example university students. For KS2 and KS3 students, respectively, lessons were created and delivered in a session either on site or in schools. The animation for younger ages features a character called "Miss Molecule", who transports heat from the reservoir to the power plant for electricity generation [40].

A Raspberry Shakes program was launched in 2018 and incorporated into the KS4 by providing nine local secondary schools with a Raspberry Shake seismograph and Raspberry Pi computers with geophones to measure ground vibration. The Raspberry Shake seismographs formed a Cornish Schools Microseismic Monitoring Network that highlighted the level of natural background seismicity in the region, which helped "normalize" discussions around the potential for induced seismicity from the geothermal project. Overall, the education program has reached 3000 students from 46 educational institutions. Positive feedback has been received from teachers, particularly from primary schools.

The outreach program was designed to ensure public engagement throughout the duration of the project, and clarity and accessibility of project information to the communities closest to the project site, as well as the wider population of Cornwall. A significant focus of the outreach was the drilling phase of the project, due to the likelihood for public concern surrounding the potential for environmental and social disturbances [40]. Due to the rise in anti-fracking protests and subsequent ban of "fracking" by the UK Government in late 2019, it was anticipated that a false association might be drawn between the targeting of natural fault zones for permeability at UDDGP and "fracking" technology used by the oil and gas industry. A Community Relations Manager was employed during the early stages of the project to work within the community. This enabled new relationships to be built between project staff and the local community. Public visits were also hosted on site, including both organized group visits to the site and site "drop-in" days. A website was created during the early stages of the project to provide information on geothermal energy and specific information about the project. Social media channels also provided a constant, reliable source of information. Short films and animation videos included a "seismicity explainer" video that was created to address initial concerns regarding induced seismicity and "fracking".

The response to this community outreach program has been overwhelmingly positive, with growing enthusiasm for geothermal development and the establishment of a new sustainable industry in Cornwall. Strong communication channels established between the project team and local community have led to the initial fears of the residents being unfounded.

\section{Geothermal Energy in Canada}

The Canadian interest for the development of geothermal energy sources started around 1972/1973 as a consequence of the diesel price rise and reserves decline forecasts [56]. Prior to the 1970s, geothermal energy sources were restricted to direct use applications, such as hot springs and spas in Western Canada [57]. The first governmental program to investigate the geothermal potential of Canada, the Geothermal Energy Program, began in 1976 but was terminated a decade later in 1986, motivated mostly by the oil-price drop, but also due to the perception of geothermal energy as a high capital risk [57-59]. Almost 5 decades have passed since Canada started seeing geothermal energy sources from an industrial point of view, rather than only for ludic activities. In the Western Canadian Sedimentary Basin, three major deep geothermal direct-use and power projects 
are progressing: the Clarke Lake geothermal project, the Alberta \#1 Greenview project, and the DEEP Earth Energy Production project.

\subsection{The Saskatchewan DEEP Project's Geological Context}

The Williston Basin is an inter-cratonic basin centrally located on the North American continent straddling the Canadian American border (Figure 9). It is an ellipsoidal bowl-shaped depression that forms the southwest extremity of the Western Canadian Sedimentary Basin. Oil was first discovered in the Williston Basin in Southeastern Montana in the 1920s and in North Dakota in 1951 and subsequently, more than 115,000 wells have been drilled. The sedimentary section of the Williston Basin reaches a thickness of over $4800 \mathrm{~m}$ in Northern North Dakota and the stratigraphic section demonstrates that the predominant depositional environment was a shallow sea from the Cambrian until the late Cretaceous. DEEP is developing its geothermal project from an HSA at the base of the Williston Basin, known as the Deadwood Formation.
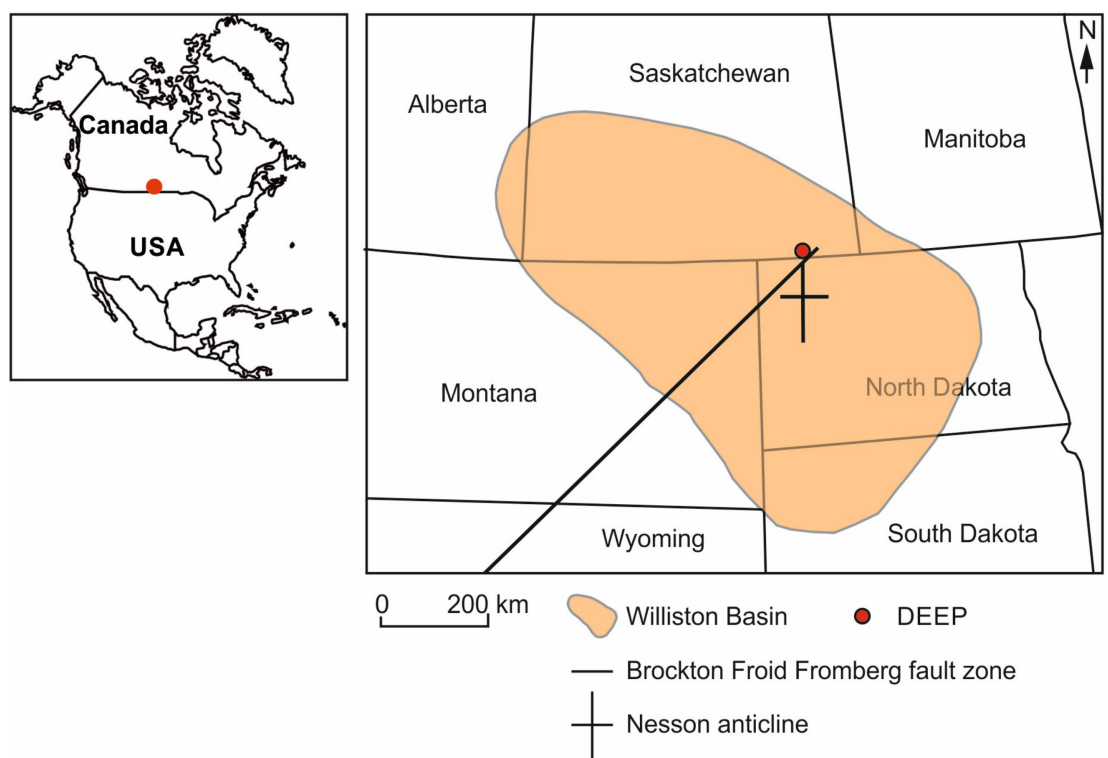

Figure 9. Williston Basin and DEEP project (red dot) location map.

The Deadwood Formation basal clastics in the Williston Basin were deposited after a long period of Precambrian erosion. The Deadwood sands represent a thick package of mature sandstones that accumulated on the Precambrian surface. The lower Cambrian Deadwood formation represents the first transgressive event as Cambrian seas transgressed the low relief and irregular Precambrian surface. Deadwood sedimentation initially started in an aeolian and dune environment directly on the Precambrian basement. This is overlain by a thick package of mature porous deltaic and fluvial sediments which grade upwards to offshore sands (informally referred to as the DEEP Sands). At this time, the deltaic focus shifted, and we see a drop in sea level and sedimentation of longshore-drift-influenced brackish lagoons and fluvial channels capped by aeolian sands and complete exposure. Final sedimentation of the Deadwood by a marine transgression resulted in deposition of a tight tidal flat carbonate package.

In the DEEP project area, the Deadwood is unconformably overlain by transgressive sandstones, siltstones and shales of the middle Ordovician Winnipeg formation. The deposition of the Winnipeg formation is contemporaneous with the initiation of the structural depression that forms the basin. The sediments of the Williston Basin are representative of all periods of the Phanerozoic. Silica diagenesis precludes porosity in parts of the Deadwood and Winnipeg Formations. Intense silica cementation takes place at updip-exposure surfaces. The texture is reminiscent to quartzite and makes an effective seal. Silicification is prevalent in the initial aeolian and dune sediments directly overlying the Precambrian 
basement and in the basal Winnipeg sands. The geochemistry of silica precipitation is associated with acidic conditions and elevated temperature, suggesting that the Deadwood may have been subjected to an even higher temperature in the past.

\subsection{DEEP Earth Energy Production Corp. Project Overview}

Injection wells for water disposal in Saskatchewan and gas wells in North Dakota demonstrate a basin-scale resource with reservoir characteristics suitable for large fluid production and injection rates; however, temperatures greater than $100^{\circ} \mathrm{C}$ are only found in the southeasterly most part of Saskatchewan and Western North Dakota. The project is unique in that it targets deep hot water in a highly productive oil region. The project has thousands of horizontal oil wells as neighbors and is located in the renowned Bakken oil trend.

DEEP's long-term strategy is to build geothermal power facilities along with direct use applications. This strategy complies with a vision of a cleaner energy future for Saskatchewan and simultaneously supports SaskPower's goal to reduce 2005 emission levels by $40 \%$ by 2030 . Produced electricity from the first facility will be sold under an existing Power Purchase Agreement with SaskPower. DEEP is exploring additional revenue streams including a commercial greenhouse development, which would be a new opportunity for the Saskatchewan agricultural sector. To date, the project has advanced with $\sim \mathrm{CAD} \$ 30 \mathrm{M}$ of Federal and Provincial funding and $\sim \mathrm{CAD} \$ 20 \mathrm{M}$ of private investment. Federal funding was announced in person in Regina, Saskatchewan, by Prime Minister Trudeau, the first renewable energy funding announcement ever made by a Prime Minister in the history of Canada. The studies performed show that the resources in this geothermal reservoir can potentially be used by power plants with capacities of more than $100 \mathrm{MWe}$. Construction of the first 20 MW facility is planned to commence in August 2021 and fully commissioned by March 2023. The DEEP project is certainly an important step toward Canada's energy transition. These first 20 MWe would reduce about 114,000 metric $t$ of $\mathrm{CO}_{2} /$ year.

\subsection{Drilling and Completion of Deep Wells}

The drilling rig is shown in Figure 10a, where, subsequent to the Border-1 discovery well completed in December 2018, four more vertical/directional wells were drilled over the 2019/2020 winter: Border-2A, Border-2B, Border-3, and Border-4 (Table 1 and Figure $10 \mathrm{~b}$ ). Border-2B was drilled starting from well Border-2A and then deviating to acquire additional data. Then, well Border- 3 was directionally drilled from the location of Border- 1 , while the vertical well Border- 4 is located southwest of the previous wells and outside the domain shown of Figure 10b.
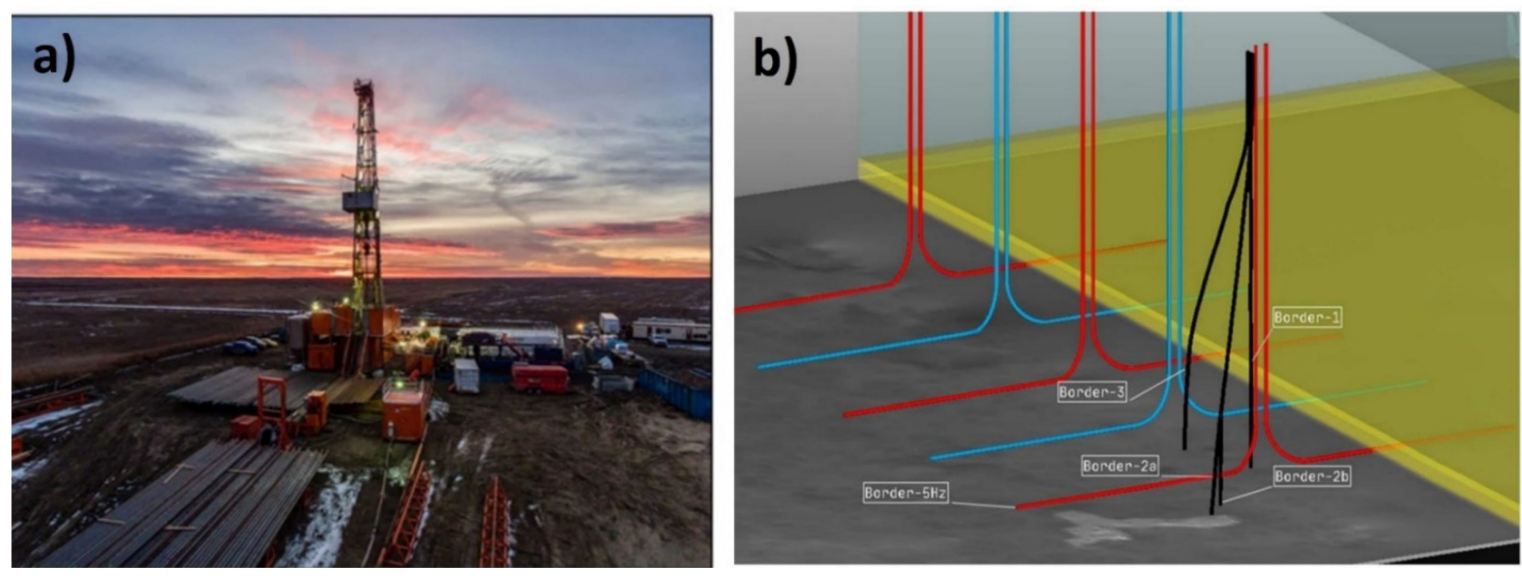

Figure 10. (a) Drilling rig for the DEEP project and (b) schematic representation of drilled wells [60]. 
Table 1. Main characteristics of wells drilled to date at DEEP project.

\begin{tabular}{|c|c|c|c|c|c|c|}
\hline Well Name & Border-1 & Border-2A & Border-2B & Border-3 & Border-4 & Border-5 \\
\hline Type & Vertical & Directional & $\begin{array}{l}\text { Whipstock } \\
\text { Directional }\end{array}$ & Directional & Vertical & Horizontal \\
\hline Drilling Days & 38 & 37 & 26 & 22 & 30 & 43 \\
\hline Drilling Costs $(\$ M)$ & 3.53 & 3.60 & 1.99 & 2.25 & 2.60 & 4.60 \\
\hline Liner Type & Slotted/Solid & $\mathrm{n} / \mathrm{a}$ & Slotted/Solid & Solid & Solid & $\begin{array}{c}\text { Solid w/Frac } \\
\text { Sleeves }\end{array}$ \\
\hline Bottom Hole Temp. $\left({ }^{\circ} \mathrm{C}\right)$ & 125 & 117 & 121 & 122 & 120 & 127 \\
\hline Well TD (mMD/mTVD) & 3530 & $3840 / 3496$ & $3890 / 3624$ & $3681 / 3560$ & 3731 & $5672 / 3731$ \\
\hline
\end{tabular}

The total amount of new hole drilled (minus above the Border-2B whipstock) was $12,279 \mathrm{~m}$. There was $185 \mathrm{~m}$ of core cut and 10 drill stem flow tests (includes 2 misruns). The intermediate section of the wells was cased with $177.8 \mathrm{~mm}\left(7^{\prime \prime}\right)$ casing. The results of this drilling program were determined in an extensive 2020 summer testing program that included a combination of flowing and injectivity tests.

A sixth horizontal well, Border-5, was drilled and hydraulically stimulated in October 2020. This was the first $90^{\circ}$ horizontal fluid production well in the world to be drilled and hydraulically stimulated for the purposes of geothermal power generation. The horizontal well was drilled to a total measured depth of $5672 \mathrm{~m}$ (3450 m vertical depth) which includes a $2000 \mathrm{~m}$ horizontal section. The well was completed with a cemented liner and a 20stage multicycle stimulation sleeve system, and hydraulically stimulated using the latest horizontal well techniques. The highest temperature measured during open-hole logging was $127^{\circ} \mathrm{C}$. No significant issues were encountered during drilling and the geological, operations and directional staff were able to maintain the well trajectory in the reservoir target zone for a significant portion of the lateral length. This well demonstrates the viability of horizontal drilling for geothermal resources in Hot Sedimentary Aquifers, supports the geophysical analysis, and further demonstrates reservoir continuity. The open hole well was tested by using a coil tubing nitrogen lift test, which indicated high permeability and flow capability with an absolute open flow capacity in the order of $20,000 \mathrm{~m}^{3} / \mathrm{d}$ or a productivity index of $0.55 \mathrm{~m}^{3} / \mathrm{d} / \mathrm{kPa}$. Successful mechanical stimulation and production modeling indicate a highly productive well-twice the productivity of an unstimulated well. This well will sustain commercial production rates $(100 \mathrm{~L} / \mathrm{s})$, while minimizing fluid drawdown. Drilling and testing results indicate that temperature and potential flow rates are sufficient to support multiple $20 \mathrm{MW}_{\mathrm{e}}$ geothermal power facilities (enough power to supply approximately 20,000 households).

\subsection{Social and Economic Implications}

The province of Saskatchewan has a long history of developing its natural resources with oil and gas being one of the leading industries as well as being the world's largest producer of potash and one of the world's largest producers of uranium. Saskatchewan is the second-largest oil-producing jurisdiction in Canada and seventh-largest onshore oil-producing jurisdiction in Canada and the United States. Improvements to horizontal oil well drilling and completion techniques have greatly improved production in the last several years. There have been $\sim 90,000$ oil and gas wells drilled in the Williston Basin on both sides of the Canadian and American border in Saskatchewan and North Dakota combined. In Saskatchewan alone, including the Williston Basin and other oil reservoirs, there has been a total of $\sim 270,000$ oil and gas wells drilled in the province [61]. The resource industry is a key economic driver in the province through royalty payments to the province from producers and major industry and job creation. As such, there is strong local support to develop provincial geothermal resources and a robust regulatory environment already exists to support it. This strong provincial regulatory environment for drilling and exploration is a key strength in the DEEP geothermal project. Licensing for drilling deep wells is a commonplace activity, which is not the case elsewhere in the world, since it is 
benefiting from the enormous experience of Canada's oil and gas mining industry and it is converting the workforce to new forms of clean, renewable, and sustainable energy.

The project is attracting, for the first time, a diverse and innovative labor force that has been previously geared only to fossil fuel production. DEEP's geothermal project has been locally championed as a way to both literally and figuratively develop a new clean energy industry on the backs of the oilfield industry and has been benefited from co-funding and continued logistical and authorization support from Natural Resources Canada. The effects on the labor market in the country have seen the redeployment of workers with high technological and scientific profiles on a renewable energy project.

\section{Discussion and Conclusions}

The three geothermal drilling projects presented here, the CFDDP in Italy, the UDDGP in the United Kingdom, and the DEEP in Canada, show that the development of unconventional resources can be achieved with proper scheduling, scientific knowledge, technical expertise, and communication with local communities and stakeholders. The characterization of caldera-hosted geothermal resources, Enhanced Geothermal Systems in granite basement, and Hot Sedimentary Aquifers are the three different geological contexts described here. The drilling depth reached in each site is different, but the enthalpy of the fluids is comparable, since the geothermal gradient is higher in the Campi Flegrei Caldera (about $220^{\circ} \mathrm{C} / \mathrm{km}$ ) than in the UK and Canadian sites, where almost the same gradient is observed $\left(37^{\circ} \mathrm{C} / \mathrm{km}\right)$, as shown in Table 2 .

Table 2. Summary of the main characteristic of the three geothermal drilling projects considered.

\begin{tabular}{lcccccc}
\hline $\begin{array}{l}\text { Project } \\
\text { Acronym }\end{array}$ & Country & $\begin{array}{c}\text { Maximum } \\
\text { Drilled } \\
\text { Depth TVD }\end{array}$ & $\begin{array}{c}\text { Bottom/Hole } \\
\text { Temperature }\left({ }^{\circ} \mathbf{C}\right)\end{array}$ & $\begin{array}{c}\text { Geothermal } \\
\text { Gradient } \\
\left({ }^{\circ} \mathbf{C} / \mathbf{k m}\right)\end{array}$ & $\begin{array}{c}\text { Period of } \\
\text { Drilling } \\
\text { Activities }\end{array}$ & $\begin{array}{c}\text { Number of Wells } \\
\text { Drilled to Date } \\
\text { in Each Project }\end{array}$ \\
\hline CFDDP & Italy & 500 & $\sim 110$ & 220 & 2012 & 1 \\
UDDGP United Kingdom & 5057 & 187 & 127 & 37.2 & 2019 & 2 \\
DEEP & Canada & 3450 & 36.8 & $2019-2020$ & 6 \\
\hline
\end{tabular}

From the technical point of view, the CFDGP allowed the application of real-time mud-gas analysis technique, which has been shown to be a valuable and operationally simple way to obtain qualitative information about the fluid contents in a specific drilled section. The method described above is operationally simple and relatively inexpensive. Because the mud-gas samples are taken during drilling, it also helped to decide if and at what depth, rock or fluid samples should be taken. A good correlation between the fluid's changes and lithology of the drilling core has been identified. $\mathrm{CH}_{4}, \mathrm{He}$, and with limitations $\mathrm{CO}_{2}$ and $\mathrm{H}_{2}$ are most suitable for detection of fluid-bearing horizons, such as shear zones, open fractures, and sections of enhanced permeability. This technique can be used with other gas of interest depending on the industrial application (i.e., geothermal, oil and gas, etc.).

At the UDDGP project, detailed analysis of the cuttings allowed for a qualitative overview of the relationship between mineralogy and the concentration of radiogenic components, which helped to constrain local heat-flow data and led to a new classification of granite types based on their Th, U, and K ratios. Significant peaks in gamma correlated with mineral rich lodes (veins) provided additional evidence for fractures. Other structural features were indicated by notable changes in the cuttings, which corresponded to zones of losses recorded whilst drilling. QEMSCAN and SEM analysis were used to establish the mineralogical differences between the fractured zones and surrounding granite.

DEEP's subsurface "fishbone" geothermal field design is globally unique and is a transformative application of modern oil and gas drilling, completion, stimulation design, and field execution techniques applied for the first time on a renewable energy project. The drilling for this project is being advanced by local world class oilfield expertise and redeploying that uniquely skilled workforce into a new clean energy industry for Canada. 
Stimulated horizontal wells drilled at a similar elevation are planned in the final completion phase of the project to implement production and injection well doublets. This anticipated well-field design is significantly different from what was used at the UDDGP project, with production and injection wells at different elevation levels.

The activities conducted in these three projects highlight the importance of proper communication and establishment of outreach programs. In Italy, the CFDDP experience shows that misunderstanding about technical aspects can stop a research project. A lesson learnt from the shallow pilot hole drilling is that a better communication among academia, politicians, stakeholders, and communities is required for the second phase of the project, whose target is a $3500 \mathrm{~m}$-deep well, aiming to reach supercritical fluids inside the caldera. In contrast, in the UK, the outreach program was established one year before drilling started, and the phased approach taken, helped to build trust in the project leading to its increased acceptance.

The developers of deep geothermal projects, as well as of any other energy generation plant, have the responsibility to clearly share the information about their projects, indicating the potential environmental impacts and their mitigation measures, the employment opportunities, and the benefits of electricity generation from renewable sources. The comparison among different energy sources, the divulgation of basic scientific and technical topics, and the promotion of public consciousness of our energy need and consumption are important aspects that should be included in community outreach programs. However, the obstacles that can be encountered with the opposition of local communities are site-specific, besides being related to economic, social, and political context of each country. Considering the three sites analyzed here, the population density is very different, which may explain the local communities' reactions to each project (Table 3).

Table 3. Population density in the regions of the three geothermal projects reviewed.

\begin{tabular}{ccccc}
\hline Country & Site & $\begin{array}{c}\text { Population Density } \\
\text { Residents/km }\end{array}$ & Year & Source \\
\hline Italy & City of Naples & 8091 & 2020 & ISTAT [62] \\
United Kingdom & Cornwall county & 161 & 2018 & Office for National Statistics [63] \\
Canada & Southern Saskatchewan province & $<2$ & 2020 & Statistics Canada [64] \\
\hline
\end{tabular}

A further aspect to be considered for social acceptability is also the vocation of the territory, which differs greatly in the various cases analyzed of Campi Flegrei (its volcanic context and geothermal manifestations), Cornwall (its mining heritage) and Southern Saskatchewan (its oil and gas history). The Phlegraean Fields represent a portion of the famous Campania Felix defined by the Romans where numerous centers of Greek civilization first and then Roman civilization settled. The fertility of the soil of volcanic nature and the availability of geothermal resources has been a focal point for the development of the area. In the 1970s, there were two periods of strong bradyseism (1970-1972 and 1983-1984) in which there has been a gradual relocation of the inhabitants of the area of Pozzuoli in neighboring areas. It is precisely during this period that there was a resumption of geothermal exploration with the drilling of wells reaching considerable depths (Table 4). However, this research activity was abandoned for reasons related to the phenomena of bradyseism, until 2012 with the drilling of the CFDDP pilot well. In Cornwall, the two wells of the UDDGP project are the only ones drilled in the area aside from mining exploration boreholes (Table 4). Geothermal development is looking to restore jobs and boost the local Cornwall economy producing electricity, heat, and, hopefully, lithium [65]. The bottom hole temperature of $187^{\circ} \mathrm{C}$ from the production well was ascertained during production testing in August 2020. The project is currently in its testing phase with plans to build a commercial power plant supplying $3 \mathrm{MW}$ of electricity later in the year. 
Table 4. Main characteristic of the drilling activities (geothermal and oil and gas) at each site.

\begin{tabular}{cccc}
\hline Site & Country & $\begin{array}{c}\text { Period of Drilling } \\
\text { Activities }\end{array}$ & $\begin{array}{c}\text { Number of Wells } \\
\text { Drilled to Date }\end{array}$ \\
\hline Campi Flegrei [19,22] & Italy & $1939-2020$ & 28 \\
Cornwall [24] & United Kingdom & 2019 & 2 \\
Williston Basin [61] & Canada & $1982-2020$ & $\sim 90,000$ \\
\hline
\end{tabular}

A drilling project is therefore site- and technology-specific: in the UDDGP project, the community outreach and education program played a central role in achieving drilling goals, while for DEEP licensing was straightforward because of the numerous oil and gas wells in the region. In CFDDP, on the other hand, a serious controversy was generated, involving the population, scientists, and politicians, in a densely populated area. Finally, while the CFDDP is a scientific project, those in the UK and Canada are industry driven and this review is a first initiative to compare scientific and industrial geothermal drilling projects. This comparison shows that each geothermal drilling project has its own history, not only because of the different geological context and technical challenges, but also because the different approaches with the local communities, as well as cultural aspects related with history, economy, and politic of each country.

Among other recent experiences, the ongoing IDDP project in Iceland has provided interesting new insights for the scientific community. The IDDP- 2 well drilled in 2017 is the first well that exceeds not only critical temperatures, which was already observed in countries such as Italy, Mexico, or Japan, but also critical pressures, in the history of geothermal drilling [66]. On the other hand, EGS development in France has shown successful experiences, with the Soultz-sous-Forêts power plant [67], where, after 30 years of research, a binary power plant has started operation in 2016, as well as with the Rittershoffen geothermal heat plant, successfully providing an average of $22.5 \mathrm{MWt}$ and $180 \mathrm{GWh}$ /year of heat since June 2016 [68]. Successful examples of unconventional geothermal development are also given by Croatia, with the plant in Velika Ciglena [69], and Germany, with the Landau plant [70].

However, in several regions of France, people opposed to hydraulic stimulation for geothermal energy, since they point out the risk of induced seismicity, as it happened according to recent news [71]. On the other hand, the interest for geothermal power production is growing in the oil and gas industry whose technical drilling expertise and innovations can readily be applied to develop geothermal reservoirs, as in the case of the DEEP project. Other recent technological development for geothermal systems includes closed deep borehole heat exchangers, such as the Advanced Geothermal Systems described by Wang et al. [72] and the Closed-Loop Geothermal (CLG) technologies, in their early commercialization stages, that use deep ground heat exchangers for power generation [73].

The motivation for promoting this kind of drilling projects lies in the transition from fossil fuels to green energies, particularly in in Canada and the UK; in Italy, although the Naples area has no oil and gas or mining tradition, as it is the case of the UDDPG and DEEP projects, the use of geothermal resources can contribute to the development of geoenergy in that area. The three case studies described here indicate that drilling techniques and reservoir characterization methods are currently available for the development of unconventional geothermal resources (EGS, HSA, and supercritical fluids), contributing to the transition between non-renewable resource development (mineral in the UK, and oil and gas in Canada, just to highlight the examples given here), to renewable geothermal resources.

Author Contributions: Conceptualization, D.B., J.R., and R.S.; methodology, L.C., M.C., A.F., M.J.J., R.S., and T.W.; validation, D.B., L.C., M.C., G.D.N., M.J.J., K.M., M.M., J.R., R.S., and T.W.; formal analysis, D.B., L.C., M.C., G.D.N., A.F., M.J.J., K.M., M.M., J.R., R.S., C.T., and T.W.; investigation, L.C., M.C., G.D.N., A.F., M.J.J., K.M., M.M., J.R., R.S., C.T., and T.W.; resources, D.B., L.C., M.C., A.F., M.J.J., K.M., M.M., J.R., R.S., and T.W. data curation, D.B., L.C., M.C., G.D.N., A.F., M.J.J., K.M., M.M., J.R., 
R.S., and T.W.; writing—original draft preparation, D.B., L.C., M.C., G.D.N., A.F., M.J.J., K.M., M.M., J.R., R.S., and T.W.; writing-review and editing, D.B., L.C., M.C., G.D.N., M.J.J., K.M., M.M., J.R., R.S., and T.W.; supervision, D.B., J.R., and R.S.; project administration, G.D.N., R.S., C.T. (CFDDP), K.M. (DEEP), L.C., and M.C. (UDDGP); funding acquisition, G.D.N. (CFDDP), K.M. (DEEP), L.C., and M.C. (UDDGP). All authors have read and agreed to the published version of the manuscript."

Funding: This research was co-funded by ICDP consortium and INGV for the CFDDP. Grant number CFDDP 05-2008.

Institutional Review Board Statement: Not applicable.

Informed Consent Statement: Not applicable.

Data Availability Statement: Not applicable.

Acknowledgments: We acknowledge Sebastian Cordoba for helping to format the references and the IGCP636 project "Geothermal resources for energy transition" belonging to the International Geoscience Program funded by United Nations Educational, Scientific and Cultural Organization (UNESCO) and International Union of Geological Sciences (IUGS) to which RS, DB, JR, LC, MC are members. We acknowledge 6 anonymous reviewers who contributed to the improvement of this manuscript.

Conflicts of Interest: The authors declare no conflict of interest.

\section{Abbreviations}

$\begin{array}{ll}\text { API } & \text { American Petroleum Institute } \\ \text { BGS } & \text { British Geological Survey } \\ \text { CFC } & \text { Campi Flegrei caldera } \\ \text { CFDDP } & \text { Campi Flegrei Deep Drilling Project } \\ \text { CFDP-1 } & \text { Campi Flegrei Deep Project Pilot hole } \\ \text { DEEP } & \text { Earth Energy Production in Canada } \\ \text { EGS } & \text { Enhanced Geothermal System } \\ \text { ENEL } & \text { Ente nazionale per l'energia elettrica } \\ \text { AGIP } & \text { Azienda Generale Italiana Petroli } \\ \text { FMI } & \text { Full Bore Imaging } \\ \text { HSA } & \text { Hot Sedimentary Aquifer } \\ \text { HDRs } & \text { Hot Dry Rocks } \\ \text { ICDP } & \text { International Continental Drilling Project } \\ \text { IDDP-2 } & \text { Iceland Deep Drilling Project well-2 } \\ \text { INGV } & \text { Istituto Nazionale di Geofisica e Vulcanologia } \\ \text { ISTAT } & \text { Istituto Nazionale di Statistica } \\ \text { NYT } & \text { Neapolitan Yellow Tuff } \\ \text { PTF } & \text { Porthtowan Fault } \\ \text { QMS } & \text { Quadrupole Mass Spectrometer } \\ \text { SLO } & \text { Social License to Operate } \\ \text { UD-1 } & \text { Deep production well UDDGP } \\ \text { UD-2 } & \text { Injection well UDDGP } \\ \text { UDDGP } & \text { United Downs Deep Geothermal Power } \\ \text { UNESCO } & \text { United Nations Educational, Scientific and Cultural Organization }\end{array}$

\section{References}

1. Simmons, S.F. Geothermal Resources. In Encyclopedia of Geology, 2nd ed.; Alderton, D., Elias, S.A., Eds.; Elsevier: Amsterdam, The Netherlands, 2021; pp. 708-722. ISBN 978-0-08-102909-1.

2. Saemundsson, K.; Axelsson, G.; Steingrímsson, B. Geothermal systems in global perspective. In Proceedings of the Short Course on Surface Exploration for Geothermal Resources, Santa Tecla/Ahuachapán, El Salvador, 17-30 October 2009.

3. Moeck, I. Catalog of geothermal play types based on geologic controls. Renew. Sustain. Energy Rev. 2014, 37, 867-882. [CrossRef]

4. Kruszewski, M.; Wittig, V. Review of failure modes in supercritical geothermal drilling projects. Geotherm. Energy 2018, 6, 1-29. [CrossRef]

5. Fajar, A.; Yamada, R.; Uno, M.; Okumura, S.; Tsuchiya, N. Evaluation of Caldera Hosted Geothermal Potential during Volcanism and Magmatism in Subduction System, NE Japan. Geofluids 2019, 19, 14. [CrossRef] 
6. Chiodi, A.; Tassi, F.; Báez, W.; Filipovich, R.; Bustos, E.; Glok Galli, M.; Suzaño, N.; Ahumada, F.M.; Viramonte, J.G.; Giordano, G.; et al. Preliminary conceptual model of the Cerro Blanco caldera-hosted geothermal system (Southern Puna, Argentina): Inferences from geochemical investigations. J. South Am. Earth Sci. 2019, 94, 102213. [CrossRef]

7. Tsuchiya, N. Potential Candidates of Supercritical Geothermal Reservoir. In Proceedings of the Geothermal Resources Council 41st Annual Meeting-Geothermal Energy: Power To Do More (GRC 2017), Salt Lake City, UT, USA, 1-4 October 2017; pp. 1587-1598.

8. Goff, F.; Janik, C.J. Geothermal Systems; Academic Press: Cambridge, MA, USA, 2000; p. 1415.

9. Friðleifsson, G.O.; Elders, W.A.; Zierenberg, R.A.; Stefánsson, A.; Fowler, A.P.G.; Weisenberger, T.B.; Harðarson, B.S.; Mesfin, K.G. The Iceland Deep Drilling Project $4.5 \mathrm{~km}$ deep well, IDDP-2, in the seawater-recharged Reykjanes geothermal field in SW Iceland has successfully reached its supercritical target. Sci. Drill. 2017, 23, 1-12. [CrossRef]

10. Harms, U.; Emmermann, R. History and status of the international continental scientific drilling program. In Continental Scientific Drilling; Harms, U., Koeberl, C., Zoback, M.D., Eds.; Springer: Berlin/Heidelberg, Germany, 2007; pp. 1-52. ISBN 978-3-54068778-8.

11. Franco, A.; Vaccaro, M. Sustainable Sizing of Geothermal Power Plants: Appropriate Potential Assessment Methods. Sustainability 2020, 12, 3844. [CrossRef]

12. Volken, S.; Xexakis, G.; Trutnevyte, E. Perspectives of informed citizen panel on low-carbon electricity portfolios in Switzerland and longer-term evaluation of informational materials. Env. Sci. Technol. 2018, 52, 11478-11489. [CrossRef]

13. Häring, M.O.; Schanz, U.; Ladner, F.; Dyer, B.C. Characterisation of the Basel 1 enhanced geothermal system. Geothermics 2008, 37, 469-495. [CrossRef]

14. Malo, M.; Malo, F.; Bédard, K.; Raymond, J. Public perception regarding deep geothermal energy and social acceptability in the province of Québec, Canada. In Geothermal Energy and Society; Allansdottir, A., Manzella, A., Pellizzone, A., Eds.; Springer: Berlin/Heidelberg, Germany, 2018; pp. 91-103. ISBN 978-3-319-78286-7.

15. Carr-Cornish, S.; Romanach, L. Differences in Public Perceptions of Geothermal Energy Technology in Australia. Energies 2014, 7, 1555-1575. [CrossRef]

16. Pellizzone, A.; Allansdottir, A.; De Franco, R.; Muttoni, G.; Manzella, A. Geothermal energy and the public: A case study on deliberative citizens' engagement in central Italy. Energy Policy 2017, 101, 561-570. [CrossRef]

17. Huang, K.K.; Hickson, C.J.; Cotterill, D.; Champollion, Y. Geothermal Assessment of Target Formations Using Recorded Temperature Measurements for the Alberta No. 1 Geothermal Project. Appl. Sci. 2021, 11, 608. [CrossRef]

18. Ricther, A. ThinkGeoEnergy's Top 10 Geothermal Countries 2020-Installed Power Generation Capacity (MWe). Thinkgeoenergy. Available online: https:/ / www.thinkgeoenergy.com/thinkgeoenergys-top-10-geothermal-countries-2020-installed-powergeneration-capacity-mwe/ (accessed on 10 February 2021).

19. Carlino, S.; Somma, R.; Troise, C.; De Natale, G. The geothermal exploration of Campanian volcanoes: Historical review and future development. Renew. Sustain. Energy Rev. 2012, 16, 1004-1030. [CrossRef]

20. De Natale, G.; Troise, C.; Mark, D.; Mormone, A.; Piochi, M.; Di Vito, M.A.; Isaia, R.; Carlino, S.; Barra, D.; Somma, R. The Campi Flegrei Deep Drilling Project (CFDDP): New insight on caldera structure, evolution and hazard implications for the Naples area (Southern Italy). Geochem. Geophys. Geosyst. 2016, 17, 4836-4847. [CrossRef]

21. Deino, A.L.; Orsi, G.; De Vita, S.; Piochi, M. The age of the Neapolitan Yellow Tuff caldera-forming eruption (Campi Flegrei caldera-Italy) assessed by $40 \mathrm{Ar} / 39$ Ar dating method. J. Volcanol. Geotherm. Res. 2004, 133, 157-170. [CrossRef]

22. Rosi, M.; Sbrana, A. Phlegrean fields. In Quaderni de la Ricerca Scientifica; Rosi, M., Sbrana, A., Eds.; Consiglio Nazionale Ricerche: Rome, Italy, 1987; Volume 114, pp. 1-175.

23. Orsi, G.; De Vita, S.; Di Vito, M. The restless, resurgent Campi Flegrei nested caldera (Italy): Constraints on its evolution and configuration. J. Volcanol. Geotherm. Res. 1996, 74, 179-214. [CrossRef]

24. De Natale, G.; Troise, C.; Somma, R. Invited perspectives: The volcanoes of Naples: How can the highest volcanic risk in the world be effectively mitigated? Nat. Hazards Earth Syst. Sci. 2020, 2037-2053. [CrossRef]

25. Erzinger, J.; Wiersberg, T.; Zimmer, M. Real-time mud gas logging and sampling during drilling. Geofluids 2006, 6, 225-233. [CrossRef]

26. Erzinger, J.; Wiersberg, T.; Dahms, E. Real-time mud gas logging during drilling of the SAFOD Pilot Hole in Parkfield, CA. Geophys. Res. Lett. 2004, 31. [CrossRef]

27. Fedele, A.; Pedone, M.; Moretti, R.; Wiersberg, T.; Somma, R.; Troise, C.; De Natale, G. Real-time quadrupole mass spectrometry of hydrothermal gases from the unstable Pisciarelli fumaroles (Campi Flegrei): Trends, challenges and processes. Int. J. Mass Spectrom. 2017, 415, 44-54. [CrossRef]

28. Erzinger, J.; Kilburn, C.R.J.; Sammonds, P.R.; Gudmondsson, A.; Fridleifsson, G.O.; Troise, C. Drilling at Campi Flegrei Caldera (Southern Italy). Available online: https: / / www.icdp-online.org/index.php?id=2126\&no_cache=1\&label=ICDP-2006/12 (accessed on 14 February 2021).

29. Goldberg, D. Well Logging for Physical Properties: A Handbook for Geophysicists, Geologists and Engineers, 2nd ed.; Eos Transactions American Geophysical Union: New York, NY, USA, 2001; Volume 82. [CrossRef]

30. Rider, M.; Kennedy, M. The Geological Interpretation of Well Logs, 3rd ed.; Rider-French Consulting Limited: Sutherland, UK, 2018; ISBN 9780954190682.

31. Serra, O. Fundamentals of Well-Log Interpretation: The Acquisition of Logging Data; Elsevier: Amsterdam, The Netherlands, 1984; ISBN 9780444426208. 
32. Tang, L.; Luo, L.Q.; Lao, C.; Wang, G.; Wang, J.; Huang, Y. Real time fluid analysis during drilling of the Wenchuan Earthquake Fault Scientific Drilling Project and its responding features. Tectonophysics 2014, 619, 70-78. [CrossRef]

33. D'antonio, M.; Civetta, L.; Orsi, G.; Pappalardo, L.; Piochi, M.; Carandente, A.; De Vita, S.; Di Vito, M.A.; Isaia, R. The present state of the magmatic system of the Campi Flegrei caldera based on a reconstruction of its behavior in the past 12 ka. J. Volcanol. Geotherm. Res. 1999, 91, 247-268. [CrossRef]

34. Pabst, S.; Wörner, G.; Civetta, L.; Tesoro, R. Magma chamber evolution prior to the Campanian Ignimbrite and Neapolitan Yellow Tuff eruptions (Campi Flegrei, Italy). Bull. Volcanol. 2008, 70, 961-976. [CrossRef]

35. Piochi, M.; Kilburn, C.R.J.; Di Vito, M.A.; Mormone, A.; Tramelli, A.; Troise, C.; De Natale, G. The volcanic and geothermally active Campi Flegrei caldera: An integrated multidisciplinary image of its buried structure. Int. J. Earth Sci. 2014, 103, 401-421. [CrossRef]

36. Vinciguerra, S.; Trovato, C.; Benson, M.; Troise, C.; De Natale, G. Understanding the Seismic Velocity Structure of Campi Flegrei Caldera (Italy): From the Laboratory to the Field Scale. Pure Appl. Geophys. 2006, 163, 2205-2221. [CrossRef]

37. Vanorio, T.; Virieux, J.; Capuano, P.; Russo, G. Three-dimensional seismic tomography from P wave and S wave microearthquake travel times and rock physics characterization of the Campi Flegrei Caldera. J. Geophys. Res. 2005, 110. [CrossRef]

38. Sacchi, M.; De Natale, G.; Spiess, V.; Steinmann, L.; Acocella, V.; Corradino, M.; de Silva, S.; Fedele, A.; Fedele, L.; Geshi, N.; et al. A roadmap for amphibious drilling at the Campi Flegrei caldera: Insights from a MagellanPlus workshop. Sci. Dril. 2019, 26, 29-46. [CrossRef]

39. Somma, R.; Troise, C.; Zeni, L.; Minardo, A.; Fedele, A.; Mirabile, M.; De Natale, G. Long-Term Monitoring with Fiber Optics Distributed Temperature Sensing at Campi Flegrei: The Campi Flegrei Deep Drilling Project. Sense 2019, 19, 1009. [CrossRef]

40. Cotton, L.; Gutmanis, J.; Shail, R.K.; Dalby, C.; Batchelor, A.; Foxford, A.; Rollinson, G. Geological Overview of the United Downs Deep Geothermal Power Project, Cornwall, UK. In Proceedings of the World Geothermal Congress, Reykjavik, Iceland, 24-27 October 2020.

41. Downing, R.A.; Gray, D.A. Geothermal Energy the Potential in the United Kingdom; HMSO: Nottingham, UK, 1986 ; p. 187.

42. Francis, M.F. Investigation of the South West England Thermal Anomaly Zone. Ph.D. Thesis, Imperial College, London, UK, 1980.

43. Tammemagi, H.Y.; Wheildon, J. Terrestrial heat flow and heat generation in the south-west England. Geophys. J. Int. 1974, 38, 83-94. [CrossRef]

44. Tammemagi, H.Y.; Wheildon, J. Further data on the South-west England heat flow anomaly. Geophys. J. Int. 1977, 49, 531-539. [CrossRef]

45. Sams, M.S.; Thomas-Betts, A. 3-D numerical modelling of the conductive heat flow of SW England. Geophys J. 1988, 92, 323-334. [CrossRef]

46. Parker, R.H. Hot Dry Rock Geothermal Energy: Phase 2B Final Report of the Camborne School of Mines Project; Pergamon Press: Oxford, UK, 1989.

47. MacDonald, P.; Stedman, A.; Symons, G. The UK geothermal hot dry rock R \&D programme. In Proceedings of the Seventeenth Workshop on Geothermal Reservoir Engineering, Stanford University, Stanford, CA, USA, 22-24 January 1992.

48. Evans, C.D.R. The Geology of the Western English Channel and Its Western Approaches; British Geological Survey; HMSO: London, UK, 1990.

49. Chen, Y.; Clark, A.; Farrar, E.; Wasteneys, H.; Hodgson, M.; Bromley, A. Diachronous and independent histories of plutonism and mineralization in the Cornubian Batholith, southwest England. J. Geol. Soc. Lond. 1993, 150, 1183-1191. [CrossRef]

50. Beamish, B.; Busby, J. The Cornubian geothermal province: Heat production and flow in SW England estimates from boreholes and airborne gamma-ray measurements. Geotherm. Energy 2016, 4, 4. [CrossRef]

51. British Geological Survey TellusSW. Airborne Geophysical Data WMS. Available online: https://www.bgs.ac.uk/technologies/ web-map-services-wms/tellussw-airborne-geophysical-data-wms / (accessed on 17 February 2021).

52. United Downs Deep Geothermal Power Project. Available online: https://geothermalengineering.co.uk/united-downs/ (accessed on 20 February 2021).

53. Ledingham, P.; Cotton, L.; Law, R. The United Downs Deep Geothermal Power project. In Proceedings of the 44th Workshop on Geothermal Reservoir Engineering, Stanford University, Stanford, CA, USA, 11-13 February 2019.

54. Leveridge, B.E.; Holder, M.T.; Goode, A.J.J. Geology of the country around Falmouth. In Memoir of the British Geological Survey; England and Wales: Nottingham, UK, 1990; Sheet 352.

55. Simons, B.J.; Shail, R.K.; Anderson, J. The petrogenesis of the Early Permian Variscan granites of the Cornubian Batholith. Lower plate post-collisional peraluminous magmatism in the Rhenohercynian Zone of SW England. Lithos 2016, 260, 76-90. [CrossRef]

56. Souther, J.G. Geothermal power, the Canadian potential. Geosci. Can. 1976, 3, 14-20.

57. Thompson, A. Geothermal development in Canada: Country update. In Proceedings of the World Geothermal Congress, Bali, Indonesia, 25-29 April 2010.

58. Jessop, A.M. Geothermal energy in Canada. Geosci. Can. 1998, 25, 33-41. [CrossRef]

59. Jessop, A. Review of National Geothermal Energy Program Phase 2-Geothermal Potential of the Cordillera (Report No.: Open File 5906); Natural Resources Canada: Ottawa, Canada, 2008. [CrossRef]

60. DEEP Earth Energy Production Corp. Available online: https://deepcorp.ca/gallery/ (accessed on 15 February 2021).

61. Geoscout Data Base. Available online: https://www.geologic.com/products/ (accessed on 22 February 2021). (license required for access). 
62. Geo Demo ISTAT. Available online: http://demo.istat.it/popres/index.php?anno=2020\&lingua=ita (accessed on 20 February 2021).

63. Cornwall Population Statistics. Available online: https://www.plumplot.co.uk/Cornwall-population.html (accessed on 20 February 2021).

64. Population and Demography Statistics. Available online: https://www.statcan.gc.ca/eng/subjects-start/population_and_ demography (accessed on 20 February 2021).

65. Taylor, K. Electricity, Heat and Lithium: Geothermal Offers New Hope for Old Mining County. 2021. Available online: https://www.euractiv.com/section/energy/news/electricity-heat-and-lithium-geothermal-offers-new-hopes-for-oldmining-county/ (accessed on 25 February 2021).

66. Kruszewski, M. IDDP-2 Well: A Significant Milestone for the Geothermal Industry. Available online: https://www. geoenergymarketing.com/tag/criticaltemperatures/ (accessed on 25 February 2021).

67. Gérard, A.; Genter, A.; Kohl, T.; Lutz, P.; Rose, P.; Rummel, F. The deep EGS (Enhanced Geothermal System) project at Soultzsous-Forêts (Alsace, France). Geothermics 2006, 35, 473-483. [CrossRef]

68. Douziech, M.; Ravier, G.; Perez Lopez, P.; Blanc, I. Environmental impacts of geothermal, natural gas and biomass used for heat generation at a starch plant. In Proceedings of the 1st Geoscience \& Engineering in Energy Transition Conference, Strasbourg, France, 16-18 November 2020.

69. Richter, A. The 17.5 MW Velika Ciglena Geothermal Power Plant Starts Operation in Croatia. 2018. Available online: https: / / www.thinkgeoenergy.com/the-17-5-mw-velika-ciglena-geothermal-power-plant-starts-operation-in-croatia/ (accessed on 25 April 2021).

70. Sanjuan, B.; Négrel, G.; Le Lous, M.; Poulmarch, E.; Gal, F.; Damy, P.C. Main geochemical characteristics of the deep geothermal brine at Vendenheim (Alsace, France) with constraints on temperature and fluid circulation. In Proceedings of the World Geothermal Congress, Reykjavik, Iceland, 24-27 October 2020.

71. Ehkirch, V. Après Les Séismes En Alsace, Menace Sur La Géothermie. Available online: https://lexpansion.lexpress.fr/actualiteeconomique/apres-les-seismes-en-alsace-menace-sur-la-geothermie_2142307.html (accessed on 25 February 2021).

72. Wang, K.; Yuan, B.; Jia, G.; Wua, X. A comprehensive review of geothermal energy extraction and utilization in oilfields. J. Petrol. Sci. Eng. 2018, 168, 465-477. [CrossRef]

73. Van Horn, A.; Amaya, A.; Higgins, B.; Muir, J.; Scherer, J.; Pilk, R.; Ross, M. New Opportunities and Applications for Closed-Loop Geothermal Energy Systems. Grc Trans. 2020, 44, 1123-1143. 